\title{
Ectoparasite borings, mesoparasite borings, and scavenging traces in early Miocene turtle and tortoise shell: Moghra Formation, Wadi Moghra, Egypt
}

\author{
John-Paul Zonneveld, ${ }^{1}$ @ Mohamed K. AbdelGawad, ${ }^{2}$ and Ellen R. Miller ${ }^{3} \odot *$ \\ ${ }^{1}$ Department of Earth and Atmospheric Sciences, University of Alberta, Edmonton, Alberta T2 G 2E3, Canada <zonnevel@ualberta.ca> \\ ${ }^{2}$ Geology Department, Faculty of Science, Cairo University, Cairo 12613, Egypt <mkabdelgawad@sci.cu.edu.eg> \\ ${ }^{3}$ Department of Anthropology, Wake Forest University, Winston-Salem, NC 27106, USA <millerer@wfu.edu>
}

\begin{abstract}
Borings and bite marks on fossil turtle carapaces and plastra from the Miocene Moghra Formation, northern Egypt, are herein described. All fossil turtle material from Moghra exhibits ichnofossils. The positions of invertebrate borings on external surfaces of tortoise and turtle shell material at Moghra are consistent with the activities of ectoparasites or mesoparasites.

A single invertebrate ichnotaxon, Karethraichnus lakkos Zonneveld et al., 2016, occurs on Moghra tortoise fossils. This trace fossil was likely emplaced by ixodid arthropods (ticks). Bite marks assigned to Nihilichnus occur on a carapace peripheral and are interpreted to reflect postmortem scavenging. An abundant and moderately diverse assemblage of invertebrate borings characterizes Moghra aquatic turtle shells. Karethraichnus lakkos and Thatchtelithichnus holmani Zonneveld et al., 2016 traces on aquatic turtles are interpreted to reflect leech and/or trematode parasitism. Gunnellichnus moghraensis (new ichnogenus new ichnospecies) and G. akolouthiste (n. isp.) likely reflect bacterial and/or fungal infections on aquatic turtle shells that rarely dried out.
\end{abstract}

UUID: http://zoobank.org/f0a3977d-deff-4954-b196-536adc405854

\section{Introduction}

Bone-modification features are common on Mesozoic and Cenozoic vertebrate fossils and are an essential source of insight into the ecology and taphonomy of their host organisms (e.g., Behrensmeyer, 1978; Behrensmeyer et al., 1979; Fiorillo, 1987; 1990; Tappan, 1994; Hasiotis; 2004; Tapanila et al., 2004; Mikulás et al., 2006; Roberts et al., 2007; Zonneveld et al., 2016). Most bone-modification features described in the literature resulted from either predation or scavenging activities and were emplaced at some point during, or after, the host animals' death (e.g., Kaiser, 2000; Britt et al., 2006; Mikulás et al., 2006; Roberts et al., 2007; Höpner and Bertling, 2017). Vertebrate scavenging and predation activities result in tooth marks, scratch marks, and crushing of bone (e.g., Behrensmeyer, 1978; Behrensmeyer et al., 1979: Mikulás et al., 2006) whereas invertebrate scavenging can result in grooves, pits, lesions, and etchings (e.g., Rogers, 1992; Kaiser, 2000; Paik, 2000; Britt et al., 2006; Roberts et al., 2007; Cabral et al., 2011).

Turtles differ from most other vertebrates in having bodies extensively covered in dermal bone, which in turn is covered by a thin layer of keratinous nonoverlapping epidermal scales, or scutes. Although the epidermal layer protects the bone from

*Corresponding author. damage incurred by interaction of the host organism with its environment, this layer can be penetrated or bypassed by parasites and the bone modified while the host organism remains alive (Zonneveld et al., 2016). Extensive data are available on modern reptile, and in particular turtle, pathologies (e.g., Tasnádi-Kubacska, 1962; Wells, 1964; Jacobson, 2007; Rothschild, 2009; Rothschild et al., 2012, 2013). These contributions, although invaluable, focus primarily on pathologies of nonskeletonized material, somewhat complicating their application to taphonomic and ichnological investigations of fossil material. Particularly lacking in the literature are descriptions and illustrations of nonpathological bone modification features such as pits, holes, and lesions caused by invertebrate parasites.

Despite the prevalence of turtles in many continental vertebrate fossil assemblages, there remain few analyses of the occurrence, prevalence, and significance of turtle bone modification features in vertebrate fossil assemblages. Scheyer and SánchezVillagra (2007) briefly discussed histological features related to "shell rot" in the extant taxon Podocnemis erythrocephala (Spix, 1824) and in fossil Taphrosphys sulcatus Leidy, 1856. Hutchison and Frye (2001, p. 15) summarized what they referred to as "nondevelopmental pathologic injuries," including pitting, rot, and bites, on several turtle shells from the Eocene of Wyoming. The features Hutchison and Frye (2001) described actually include a mix of pathological and nonpathological features. Pathological features (sensu Bertling et al., 2006) are a systemic 
response of a host organism to disease or injury and include such features as tumorous swellings of bones, dental caries, and healed injuries to bones or carbonate and chitinous skeletons. By contrast, trace fossils are morphologically recurrent structures that resulted from the actions of one or more organisms modifying a substrate (Bertling et al., 2006). Zonneveld and others (2016) discussed the occurrence, significance, and prevalence of several distinct types of holes and pits that occur in carapace and plastron bones of the early Eocene geoemydid turtle Echmatemys sp. from the South Pass area of western Wyoming. These authors assessed the bone modification features from an ichnological perspective and established two distinct ichnogenera (Karethraichnus and Thatchtelithichnus) within which to assess the ethologies that these traces represent. Although these authors did note the occurrence of bone spurs or patches produced by some host organisms (invariably on the inner surface of fully penetrated carapace and plastron pieces), these pathological responses were not included in the diagnoses or descriptions of any ichnotaxon (Zonneveld et al., 2016; Zonneveld and Bartels, 2019).

Here we describe a suite of traces emplaced in the plastron and carapace of early Miocene turtles and tortoises from Wadi Moghra, in northern Egypt (Fig. 1). Some of these traces are interpreted as bite marks resulting from either predation or postmortem scavenging. Most are borings emplaced by a variety of invertebrates. The position of the borings on the shells is consistent with emplacement by a variety of ectoparasites/mesoparasites, arguably while the host organism was alive. Although these features were emplaced in a living substrate, they are morphologically recurrent structures that resulted from the activities of a variety of external microscopic and macroscopic organisms and thus are trace fossils rather than pathologies.

\section{Study area}

Wadi Moghra preserves a diverse suite of early Miocene vertebrates. The Moghra fauna is particularly well known for its mammals, including anthracotheres, carnivores, creodonts, artiodactyls, primates, and proboscideans (e.g., Simons, 1969; Miller, 1996; Sanders and Miller, 2002; Morlo et al., 2007, 2019). Reptiles, including crocodilians, snakes, lizards, and turtles, have been known from Wadi Moghra for well over a century (Andrews, 1901, 1904, 1905; Fourtau, 1920; El-Khashab, 1977; Georgalis et al., 2020), but these taxa have been the focus of comparably few studies (e.g., Andrews, 1899, 1901; Dacqué, 1912; Fourtau, 1920; Tchernov, 1986) although Moghra turtles have been included in analyses of individual taxonomic groups and regional distributions (e.g., de Lapparent de Broin, 2001, 2003a, b; Gaffney et al., 2011; Pérez-Garcia et al., 2016). Recently, work on crocodylians and turtles from Moghra (e.g., Abdel Gawad et al., 2014, 2018; Abdel Gawad, 2016) recorded the presence of four genera of Crocodylians (Crocodylus, Tomistoma, Euthecodon, and Rimasuchus) and five genera of Testudines (Mogharemys, Latentemys, Lemurchelys, Erymnochelys ["Podocnemis"], and Trionyx).

Wadi Moghra is located on the northeastern margin of the Qattara Depression, approximately $60 \mathrm{~km}$ south of El Alamein, Egypt (Fig. 1). The Moghra Formation consists of approximately 400 meters of siliciclastic sediments and primarily preserves a stacked landward- stepping estuarine and deltaic succession, with subordinate fully marine and fully continental intervals (Said, 1962; Miller, 1999; Hassan, 2013; Hassan et al., 2012). The majority of the fossil material discussed here was accumulated by surface collecting expeditions to Moghra, conducted at irregular intervals over the past fifty years. Most vertebrate fossils are sourced from four horizons in the lower Moghra Formation (Abdel Gawad et al., 2010, 2012; Abdel Gawad, 2011; Georgalis et al., 2020). Sediment adhering to several of the specimens described here suggests that they were also recovered from these lower beds.

\section{Materials and methods}

This manuscript is focussed on turtle fossils and the trace fossils hosted upon them. Many of these trace fossils were likely emplaced before the death of the host organism. All available turtle fossils in the collections of the Division of Fossil Primates at the Duke Lemur center and in the Natural History Museum of London were carefully analyzed for all evidence of parasite, scavenger, or predator behavior.

Terminology.-The "external surface" refers to the surface of the shell covered by keratinized layers of the epidermal epithelium (epidermal scutes). The "visceral surface" of the shell refers to the surface of the plastron or carapace against which the soft tissue of the turtle would occur during life (sensu Zonneveld et al., 2016). "Internal surface" is used for the internal parts of outlying bones (such as the epiplastra, xiphiplastra, nuchals, pygals, and some peripherals) that would have had distal components not covered by soft tissue but rather by nonoverlapping epidermal scutes, the boundaries of which form seams or "sulci." Although the epidermal scutes are not preserved in any of the fossil material discussed here, each sulcus is represented by a groove preserved on the underlying dermal bone, and thus the shapes of the original scutes can be elucidated.

Following the precedent set by previous workers (e.g., Bromley, 1981, 1993; Brett, 1985; Nielsen and Nielsen, 2001; Zonneveld et al., 2016), the noun "hole" is used to identify a perforation that penetrates all the way through a shell bone whereas "pits" terminate within the bone and do not fully penetrate from the external to the internal surface. Similarly, the adjective "penetrative" is used for ichnofossils, which pierce completely through a bone, and nonpenetrative is used for traces, which terminate within the bone (sensu Zonneveld et al., 2016).

Some workers separate the terms "trace" and "mark" to separate out structures produced by physical and biological means (e.g., Ekdale et al., 1984; Vallon et al., 2015). We avoid this restriction here, as this invokes a priori assumptions in terms of the origin of the features and is contrary to convention used in the greater ichnological, biological, zoological, anthropological, archeological, medical, and forensic literature. Thus, the term "mark" is used here for any bone modification feature regardless of a priori assumptions of origin.

In analyses of modified osteological remains, a decision must be made whether to analyze the material from an ichnological or a pathological perspective (e.g., Tasnádi-Kubacska, 1962; Wells, 1964; Hutchison and Frye, 2001; Bertling et al., 2006; Jacobson, 2007; Rothschild, 2009; Rothschild et al., 


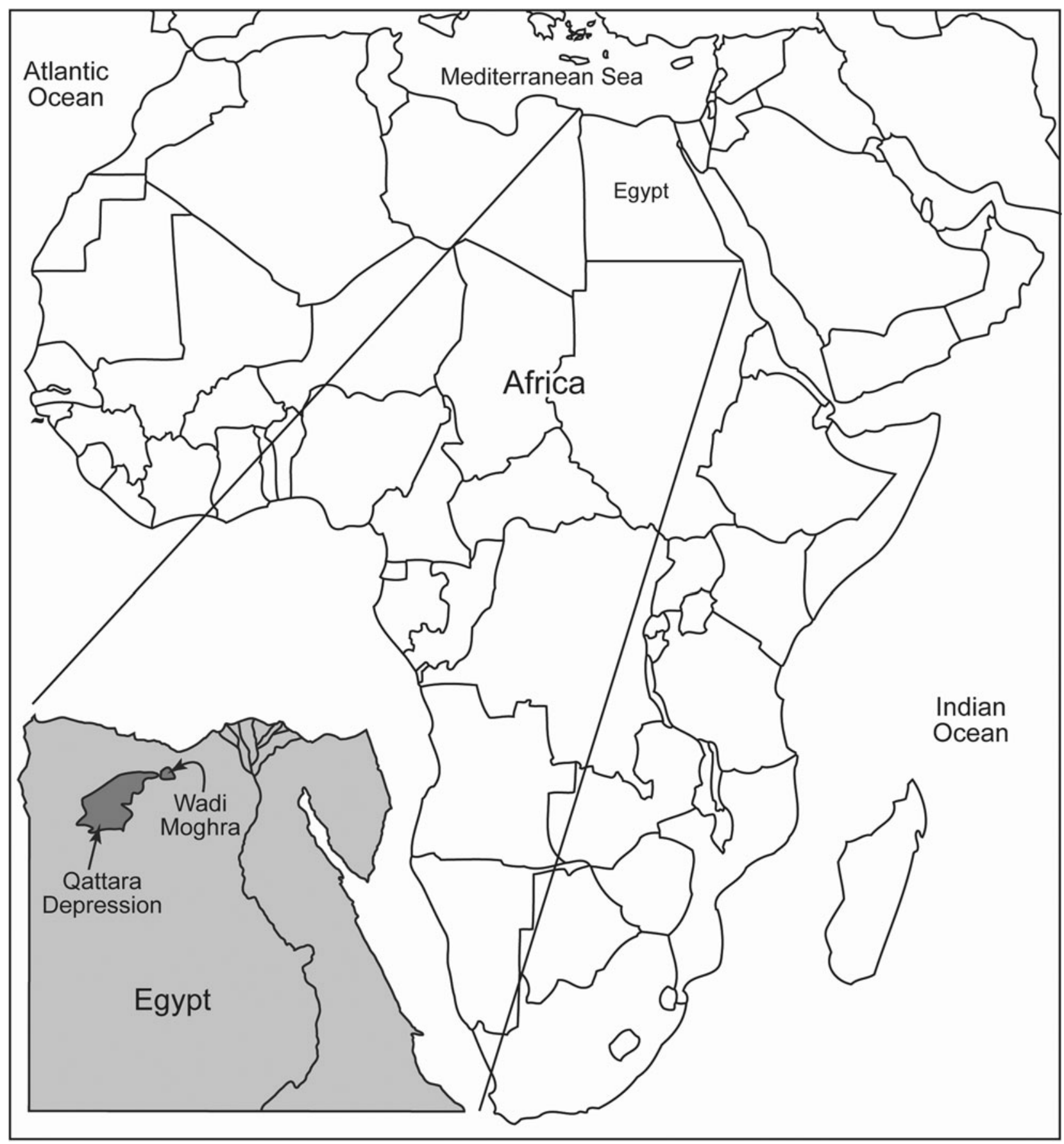

Figure 1. Map of Africa and Egypt showing the location of Wadi Moghra and the Qattara Depression.

2012, 2013). Bite and gnaw marks are typically discussed as trace fossils whereas bone or shell alterations resulting from disease are considered pathological structures (Bertling et al., 2006). Arguably, the separation can be made according to whether the structure in question resulted from the response of a host organism to a stimulus (e.g., reaction tissue on plants, galls on crinoids, bone spurs due to osteoarthritis) or, alternatively, was emplaced by an external agent (e.g., beetle borings, holes in shells, tooth grooves in bone). It is worth noting that pathologies can co-occur with trace fossils, as is the case where boring bivalves penetrate through oyster shell, stimulating a thickening of the interior shell as a response by the oyster host. In such a case, the shell boring trace fossil would be identified as Gastrochaenolites, but the thickening produced by the host organism would be a pathology. A similar situation occurs in the turtle-hosted bone-boring trace fossil Karethraichnus fiale Zonneveld et al., 2016, where a small proportion of traces observed $(<1 \%)$ prompted growth of bone spurs or patches by the host organism. Again, the borings are considered trace fossils whereas the bone spur/patch is a pathology. It is worth noting that while such compound traces have received their own name in the past (e.g., Edinger and Risk, 1994), this practice 
is discouraged (sensu Bertling et al., 2006). Penetration into a pathology cannot be a requirement for identification of a trace fossil. Thus, the ichnotaxon $K$. fiale is limited to traces that penetrate through a bone substrate but explicitly does not include any portion within bone spurs or other mineralized reaction tissue. It is also worth noting that neither the size nor the inferred taxonomy of the tracemaker is germane to trace fossil assignment. Trace fossils can be emplaced by any organism, from large carnivores (e.g., Mikuláš et al., 2006) to fungi and bacteria (e.g., Radtke and Golubic, 2005; Wisshak et al., 2008, 2018).

The material discussed here is analyzed from an ichnological perspective because a clear case can be made that all the markings, pits, grooves, lesions, and so on were emplaced by external agents/organisms. Structures that modify the Moghra bone discussed here are interpreted to be the result of the activities of a variety of other vertebrates, invertebrates, or environment-derived fungi or bacteria. Thus, these are trace fossils and subject to International Commission on Zoological Nomenclature (ICZN) rules.

Repositories and institutional abbreviations.-The trace fossils discussed here occur on turtle shell fragments (carapace and plastron) that are housed in the paleontology collections at the Division of Fossil Primates, Duke Lemur Center, Duke University, North Carolina (DPC), the Natural History Museum in London, England (NHMUK), and the University of Alberta Trace Fossil collections (UA-TF). Measurements provided for turtle shell are limited to complete carapace and plastron elements and are taken on the external surface. The precise shell element on which the borings occur is identified.

\section{Systematic paleontology: host taxa}

\author{
Order Testudines Batsch, 1788 \\ Infraorder Cryptodira Cope, 1868 \\ Superfamily Testudinoidea Batsch, 1788 \\ Family Testudinidae Batsch, 1788 \\ Infrafamily Testudininei Batsch, 1788 \\ Testudininei indeterminate
}

Figure 2

Description.-DPC 12545 is a fragment of a robust, thick-shelled turtle carapace peripheral (Fig. 2), likely peripheral R3. It is triangular in outline in both horizontal aspect and vertical profile (Fig. 2). Although clearly a tortoise peripheral, and similar to large Namibchersus or Stigmochelys (Geochelone; Fritz and Bininda-Emonds, 2007) anterior peripherals, it is nondiagnostic with respect to taxon.

Material.-DPC 12545, a single peripheral from the anterior end of the carapace (Fig. 2).

Measurements.-DPC 12545, $114 \mathrm{~mm}$ edge length; $117 \mathrm{~mm}$ posterior margin length; $115 \mathrm{~mm}$ anterior margin length; 55 mm thickness.

Remarks.-DPC 12545 is similar in size and preservation to the Namibchersus discussed in the following and, as it was collected from the same area and horizon, was likely sourced from an individual within that genus. It is a thick bone with rounded edges and was likely fluvially transported for some distance.

Genus Namibchersus de Lapparent de Broin, 2003b

Type and only species.—?Testudo namaquensis Stromer, 1926.

Diagnosis.- "Large terrestrial Testudinidae, carapace substantially exceeding $80 \mathrm{~cm}$ in length, with the schema of the suprapygal-pygal and marginals 12 of the "Geochelone" type (but with the posterior sulcus of vertebral 5 crossing the lentil in the arc of a circle toward the front) and peripherals 4 and 6 and the marginals of the bridge enlarged, rising as an arc of a circle at the expense of the pleurals; more evolved than Gigantochersina (at least where it is known) mainly by its constant peripheral points, its quadrangular neural 1 in all the cases, its dorsal epiplastral lip less projecting and al-ways with convergent margins, dorsally more elevated and recurved into an overhang in front of or up to the entoplastron, and its complete pleuro-peripheral coincidence. Morphologically close to Astrochelys yniphora (more so than in A. radiata, which is less derived).

"It is less specialised than A. yniphora by its unfused gulars and apparent absence of the gular spur present in the male of the latter, the dorsal plates are not thinned, the dorsal epiplastral lip is not concave from front to back and its form is less arched. It is more derived by the longer and more sinuous ventral lip of the nuchal plate with slight rounding of the marginals 1 border, and by the laterally shorter inguinals. It is derived following a different trend from Astrochelys by the slightly flat to convex dorsal epiplastral lip, widening behind with almost parallel gularo-humeral sulci. Other derived homoplastic features, but which are diagnostic when combined: pygal high and con-vex, especially in males; epiplastra elbowed in front of the moderate gular projection; gulars partly overlapping the entoplastron; entoplastron enlarged in the adult; elbowed humero-pectoral sulcus; the femoro-anal sulcus not notably narrowed; anal notch wide and moderately long; dorsal femoro-anal margin wide, in particular at the xiphiplastral points; the part of the femorals covering the xiphiplastra long in comparison to the anals; axillaries transverse triangular, big inguinals in an arc of a circle, from the posterior part of the marginals 7 to a small part of the femorals" (de Lapparent de Broin, 2003b, p. 75).

Occurrence.-Early Miocene of Africa (Namibia and Egypt).

Remarks.-Large terrestrial testudinids have characterized Africa since the early Oligocene, arriving from Europe in several ways throughout the late Paleogene and Neogene (Thomas et al., 1991; de Lapparent de Broin, 2003b; Holroyd and Parham, 2003). The limited material that we describe herein from the early Miocene Moghra succession is identical in morphology and shape to the type material described by de Lapparent de Broin (2003b), and thus the diagnosis of the genus is not emended or altered herein.

Namibchersus cf. N. namaquensis (Stromer, 1926) Figures 3, 4 


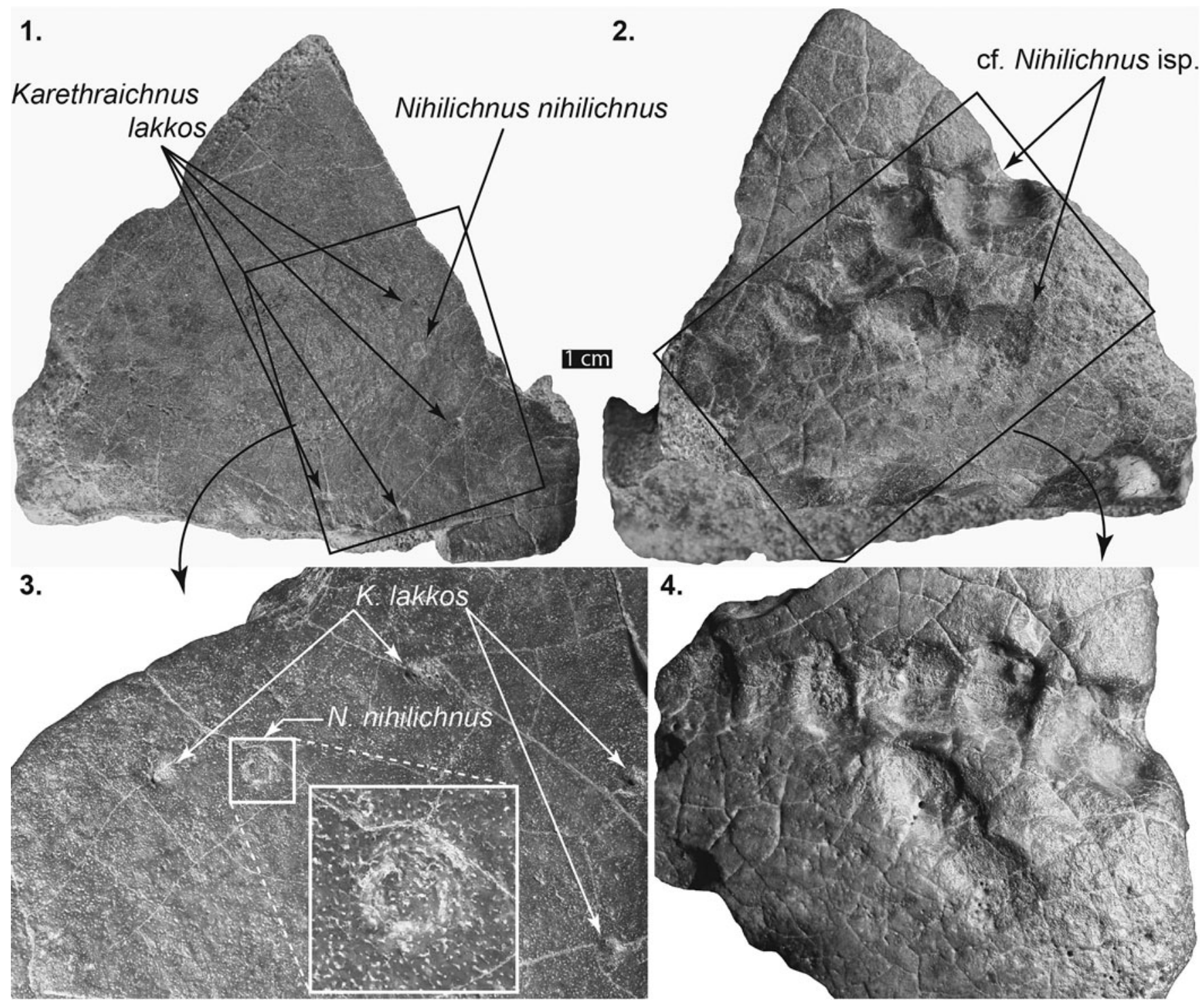

Figure 2. Left front peripheral, Testudininei indeterminate, DPC 12545. (1) Dorsal surface showing several Karethraichnus lakkos and a single Nihilichnus nihilicus. (2) Ventral surface showing two distinct groupings of aligned cf. Nihilichnus sp. (3) Close-up of (1) showing several K. lakkos and the irregular jags indicating brittle deformation that is the hallmark of $N$. nihilicus. (4) Close-up of (2) showing sediment-filled cf. Nihilichnus sp.

Description.-DPC 6443 (Figs. 3, 4) consists of a fragment of the anterior end of a very thick plastron $(37 \mathrm{~mm}$ total thickness; $12-17 \mathrm{~mm}$ platform thickness). Its size and the degree to which the plastral elements are fused suggest that DPC 6443 is likely a specimen of an older individual. The suture lines on the ventral portion of the plastron fragment are subtle, and those on the visceral surface are impossible to differentiate.

The lip of the epiplastra forms a pronounced overhang or excavation, which undercuts the lip by $9 \mathrm{~mm}$ (Fig. 4.3). The deeply excavated epiplastra and the absence of either a dorsal or ventral keel are similar to those in Stigmochelys pardalis (Bell, 1828) (e.g., Auffenberg, 1974, 1981) and to Namibchersus namaquensis (de Lapparent de Broin, 2003b). The gular sulci (Figs. 3.1, 4.2) form a distinctive heart shape that differs from that in modern and Pleistocene $S$. pardalis and from most other African Miocene tortoises (e.g.,
Auffenberg, 1974, 1981; Meylan and Auffenberg, 1986, 1987), but it is similar to the pattern in Namibchersus namaquensis. Comparison of the size of DPC 6443 with N. namaquensis material described from Namibia (de Lapparent de Broin, 2003b) indicates that DPC 6443 was a small to moderate-sized tortoise.

Material.-DPC 6443, a fragment of the anterior plastron consisting of both epiplastra and the anterior end of the entoplastron (Figs. 3, 4).

Measurements.-DPC 6443, right epiplastron: length, $72 \mathrm{~mm}$; width, $69 \mathrm{~mm}$; thickness, $37 \mathrm{~mm}$; trough depth, $20 \mathrm{~mm}$; epiplastral lip overhang, $9 \mathrm{~mm}$.

Remarks.-Namibchersus namaquensis is a basal member of the Geochelona clade of testudinids (sensu Georgalis et al., 

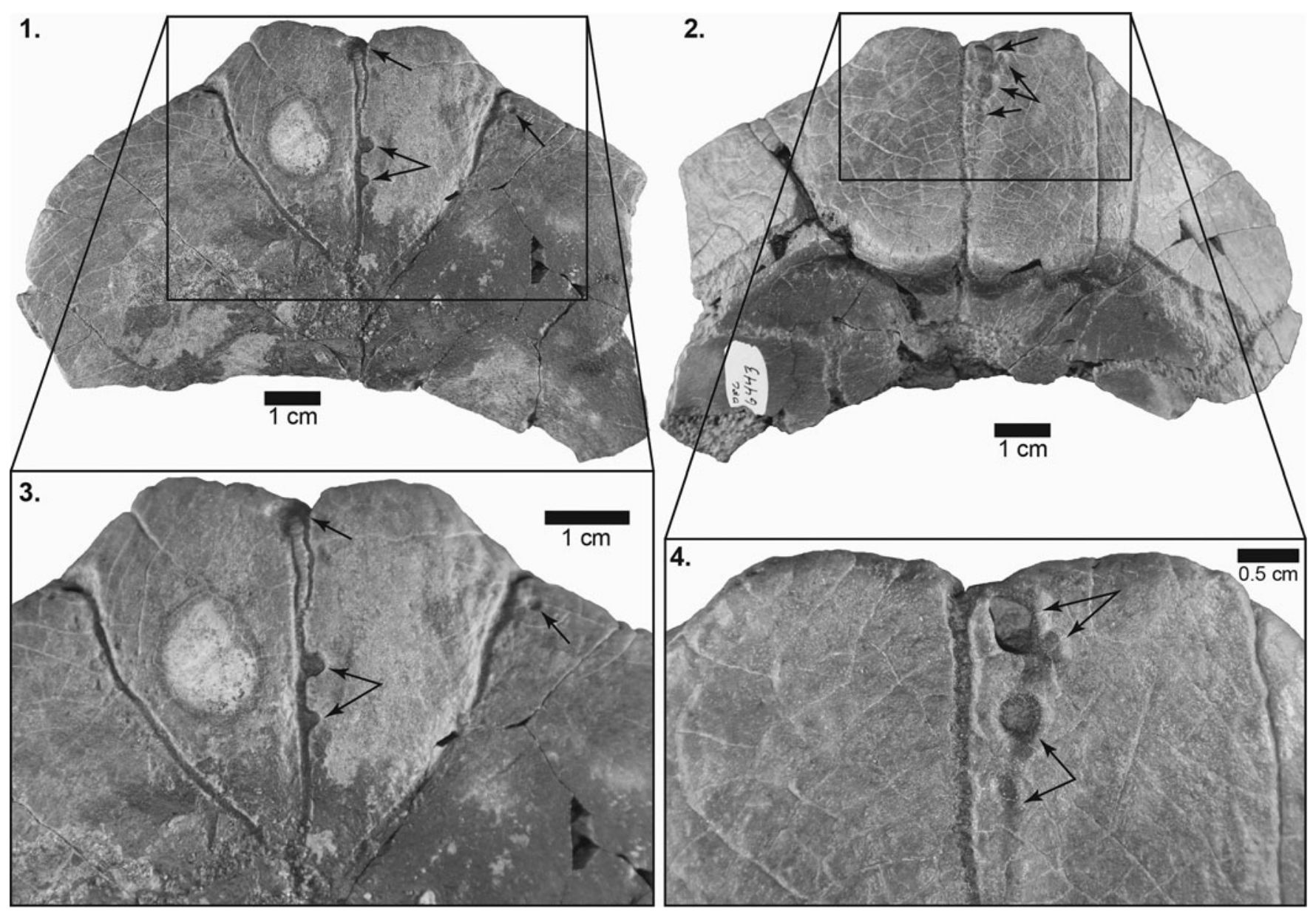

Figure 3. Anterior part of plastron, including both epiplastra and the anterior part of the entoplastron of Namibchersus sp., DPC 6443. (1) Ventral surface showing four Karethraichnus lakkos (arrows). (2) Dorsal surface showing four $K$. lakkos (arrows). Note the distinct size ranges and variable circularity of the specimens. (3) Close-up of (1). (4) Closeup of (2).
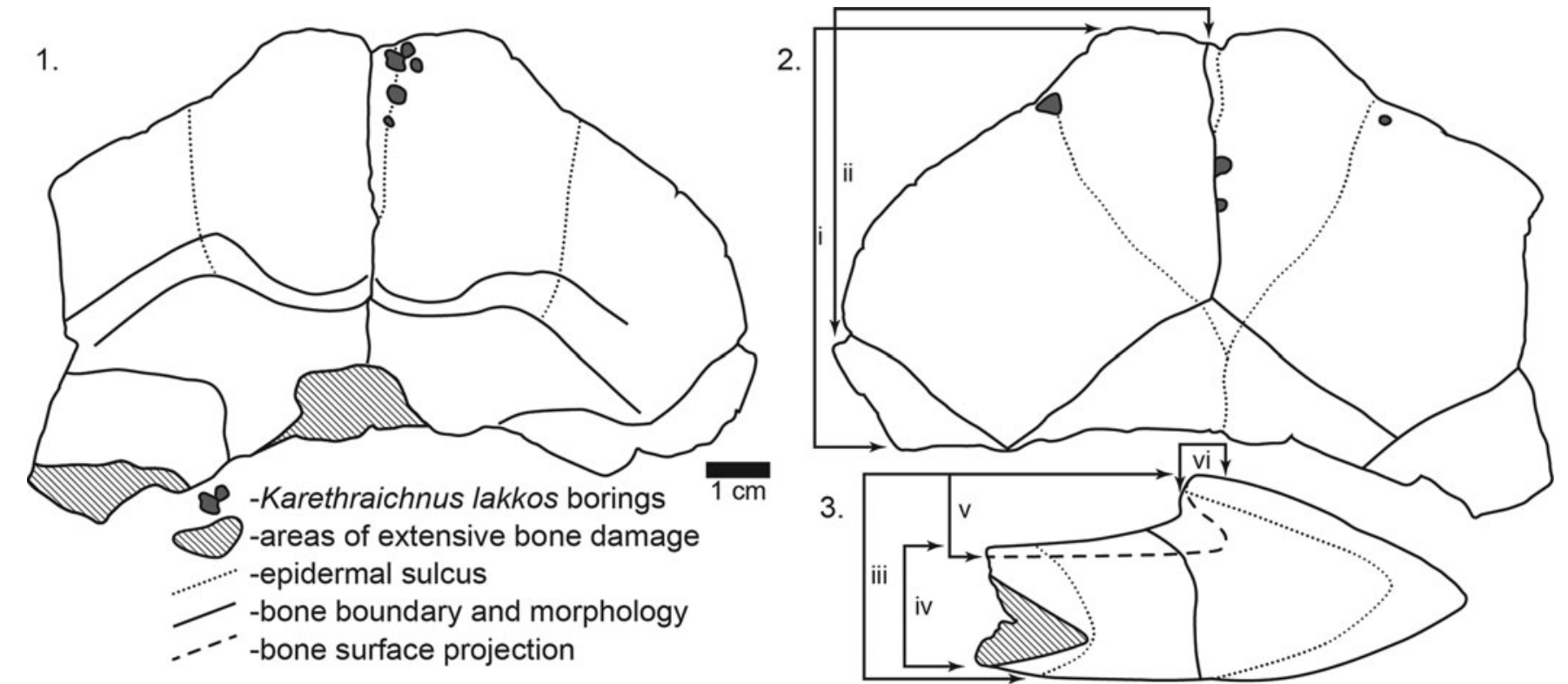

Figure 4. Line drawings of DPC 6443, Namibchersus sp. left and right epiplastra and partial entoplastron showing locations of invertebrate borings. Measurements of right epiplastron as follows: $\mathrm{i}=$ epiplastron length; $\mathrm{ii}=$ epiplastron width; iii = total epiplastron thickness; iv = posterior entoplastron thickness; $\mathrm{v}=$ epiplastron lip thickness; vi = depth of overhang of epiplastron lip. (1) Visceral/internal surface of epiplastra. (2) Ventral view of epiplastra. (3) Cross-sectional view of epiplastra. 
2021). Molecular data indicate a Paleogene (pre-late Eocene) Eurasian origin for African testudinids (Hofmeyr et al., 2017). Collision of the Afro-Arabian plate with Eurasia during the early Miocene resulted in a terrestrial corridor that facilitated faunal exchange between the two continents (Georgalis et al., 2020, 2021). The sudden appearance of multiple testudinid genera (Impregnochelys, Mesochersus, Stigmochelys, and Namibchersus) in the early Miocene at multiple localities in Africa supports a Eurasian origin for these taxa (Georgalis et al., 2021). The type material of $N$. namaquensis was collected from early Miocene strata in southwestern Africa (Stromer, 1926; de Lapparent de Broin, 2003b) and thus is similar in age to Namibchersus cf. $N$. namaquensis from Moghra. The occurrence of this taxon at Moghra further supports a Eurasian origin for this genus and indicates a widespread distribution on the African continent during the Miocene.

Suborder Pleurodira Cope, 1865

Family Podocnemididae Cope, 1868

Podocnemididae incertae sedis

Figures 5-7

Description.-Specimen NHMUK2927 is a plaster cast of the holotype of the former taxon "Podocnemis" aegyptiaca (Andrews, 1900) holotype. It consists of an incomplete carapace missing most of the peripherals and an almost complete plastron. NHMUK2960 consists of a large plastron fragment with a complete entoplastron.

Each of specimens DPC 7400 and DPC 7401 consists of the anterior half of medium-sized podocnemidid plastra (Figs. 5, 7). The entoplastron is roughly diamond-shaped on the ventral surface, with four straight sides of approximately equal length. On the visceral surface it is approximately acorn-shaped and is characterized by a triad of raised ridges, the central of which runs up the midline; the other two extend at $120^{\circ}$ from each other and from the central ridge. A low rounded ridge on the visceral surface characterizes the midline junction of the epiplastra. DPC 7400 and 7401 are morphologically identical to, albeit overall smaller than, the specimen of "Podocnemis" aegyptiaca (= Erymnochelys) that Andrews (1900) described from Moghra ( $\sim 85-90 \%$ as large). The suture lines between the dermal bone elements are well fused, suggesting that all specimens studied represent mature adults.

Material.-NHMUK2960, a partial anterior plastron consisting of the entoplastron and both hypoplastra. NHMUK2927, a plaster cast of the holotype of the former taxon "Podocnemis" aegyptiaca Andrews, 1900, nearly complete carapace and plastron. DPC 7401, the anterior half of the plastron consisting of both epiplastra, the entoplastron, the left hyoplastron, and approximately half of the right hyoplastron (Figs. 5, 6). DPC 7400 , the anterior half of the plastron consisting of both epiplastra, the entoplastron, and the left and right hyoplastra (Fig. 7).

Measurements.-NHMUK2927 (formerly known as "Podocnemis" aegyptiaca holotype): plastron width in front of bridge, $155 \mathrm{~mm}$; plastron length, $335 \mathrm{~mm}$; bridge length, $135 \mathrm{~mm}$. Entoplastron length, $64 \mathrm{~mm}$; entoplastron width, $71 \mathrm{~mm}$. NHMUK2960: entoplastron width, $78 \mathrm{~mm}$; front to back, $71 \mathrm{~mm}$. DPC 7400: entoplastron width, $56 \mathrm{~mm}$; entoplastron length, $58 \mathrm{~mm}$. Left epiplastron width, $57 \mathrm{~mm}$; front to back, $54 \mathrm{~mm}$. DPC 7401: entoplastron width, $54 \mathrm{~mm}$; front to back, $52 \mathrm{~mm}$. Left epiplastron width, $54 \mathrm{~mm}$; right epiplastron width, $54 \mathrm{~mm}$. Epiplastra length (cranial to caudal), $47 \mathrm{~mm}$.

Remarks.-Confusion remains regarding the taxonomic standing of African podocnemids (e.g., Andrews, 1900; Williams, 1954; Noonan, 2000; Gaffney et al., 2011; Pérez-Garcia et al., 2016). Andrews (1900) originally assigned Moghra podocnemids to Podocnemis aegyptiaca. Williams (1954) suggested that morphological characters of the plastron imply affinity with Erymnochelys, a taxon that was widespread in Africa during the Paleogene and Neogene (Williams, 1954; Hirayama, 1992; de Lapparent de Broin, 2003b). A single extant form, which occurs in Madagascar, remains (e.g., Kuchling, 1988; Noonan, 2000).

More recent analyses of podocnemids suggest that, in the absence of associated skull material, assignment of the Moghra material to Podocnemis is tenuous (Gaffney et al., 2011; Pérez-Garcia et al., 2016). The taxonomic name Podocnemis is now limited to South American forms, and "Podocnemis" aegyptiaca has been placed within the Erymnochelys group pending a new assignment (Pérez-Garcia et al., 2016). Following this, material previously assigned to "Podocnemis" aegyptiaca is here referred to as Podocnemididaae incertae sedis.

\section{Systematic paleontology: bone-hosted trace fossils}

Ichnogenus Nihilichnus Mikuláš et al., 2006

Type ichnospecies.—Nihilichnus nihilicus Mikuláš et al., 2006.

Other ichnospecies.-Ichnogenus is monotypic.

Diagnosis.—As for the type ichnospecies by monotypy.

Occurrence.-Paleozoic to Pleistocene, global.

Remarks.-The monotypic ichnogenus was established to include tooth marks in bone, including both solitary marks and clusters or groupings of tooth marks (Mikuláš et al., 2006). Nihilichnus differs from Mandaodonites and Heterodontichnites in the inclusion of more rectangular and triangular tooth-mark outlines and the more linear nature of the row of individual tooth marks (Cruikshank, 1986; Mikuláš et al., 2006; Rinehart et al., 2006).

\section{Nihilichnus nihilicus Mikuláš et al., 2006}

Figure 2.1, 2.3

Holotype.-Ah-1439 SGDB, an irregular hole in Miocene vertebrate skeletal material from the Merkur North opencast mine at Ahníkov, Czech Republic.

Diagnosis._-"Roughly triangular, circular or ovoid holes or external pits, occurring solitarily or in groups or clusters, which may show recurring patterns. Outer margin of the 


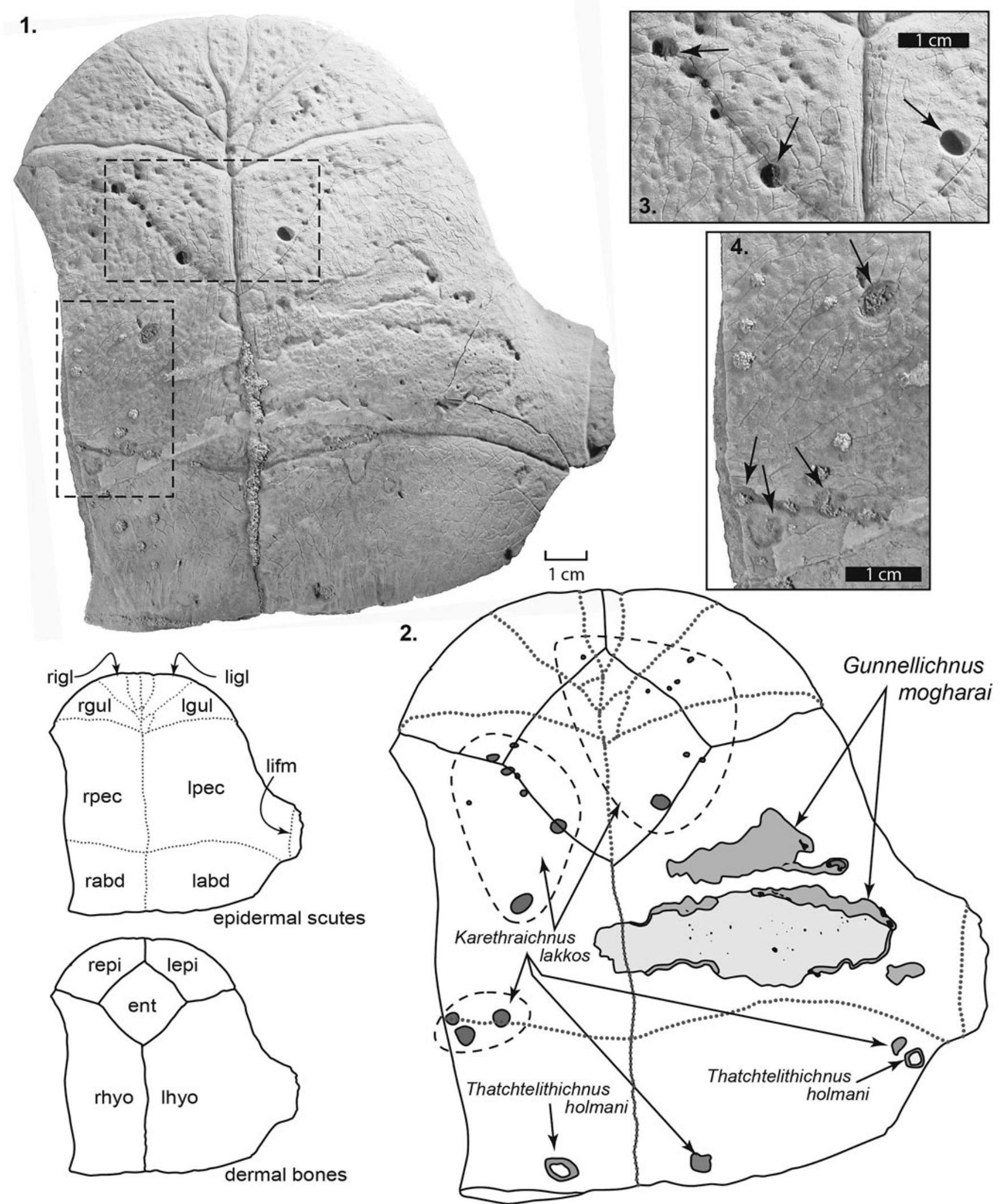

Figure 5. Front part of podocnemid plastron, DPC 7401, preserving the left and right epiplastra, the entoplastron, the right hyoplastron, and part of the left hyoplastron. Inset sketches at bottom left show the distribution of dermal bones and the location of overlying epidermal scutes (not preserved). $r=$ right; $1=$ left; igl $=$ intergular; gul = gular; pec $=$ pectoral; abd $=$ abdominal; ifm $=$ inframarginal; epi $=$ epiplastron; ent $=$ entoplastron; hyo $=$ hyoplastron. $(\mathbf{1})$ Photograph of ventral surface of DPC 7401. (2) Line drawing of the ventral surface of DPC 7401. Note the concentration of Karethraichnus lakkos near the suture lines of the entoplastron and near the epidermal sulcus between the right abdominal and right pectoral scutes. (3) Close-up of Karethraichnus lakkos on the posterior margin of the entoplastron. (4) Close-up of $K$. lakkos on the right hyoplastron and on the right pectoral-abdominal epidermal scute sulcus. 

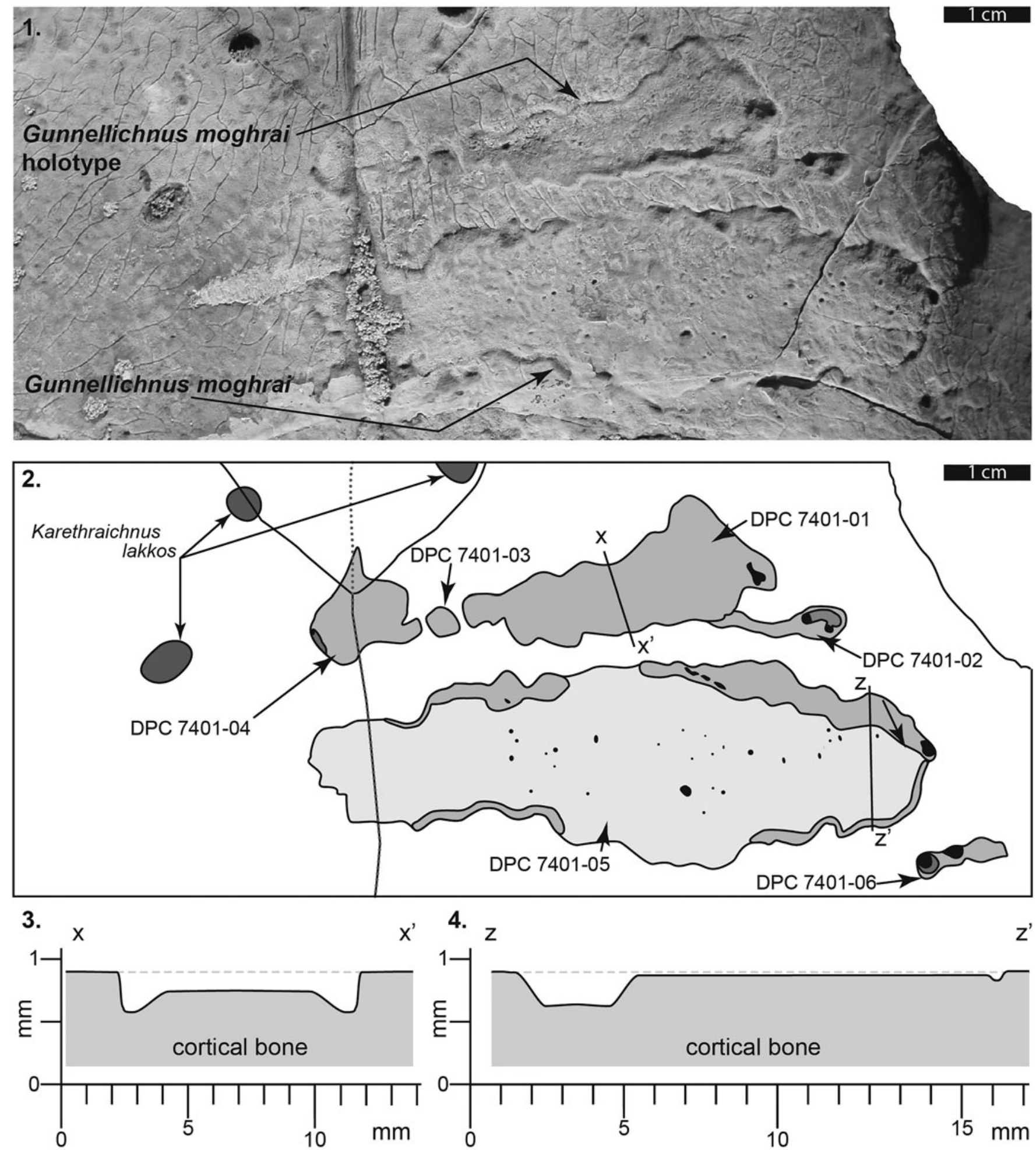

4. $z$

$z^{\prime}$

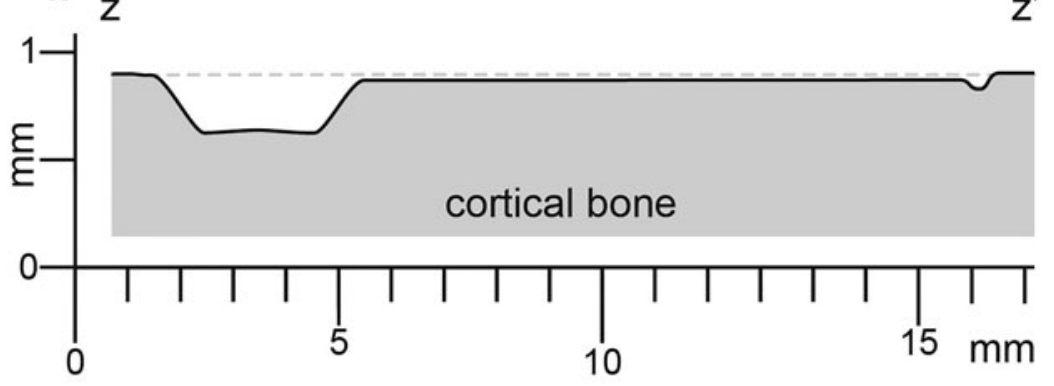

Figure 6. Left hyoplastron of DPC 7401 showing detail of the holotype of Gunnellichnus moghraensis. (1) Photograph of G. moghraensis holotype and additional specimen. (2) Line drawings illustrating the extent of Gunnellichnus moghraensis on the left and right hyoplastra. Note that darker shading indicates greater depth of penetration. (3) Schematic cross section through the center of DPC-7401-01 (G. moghraensis holotype) showing depth of penetration into the cortical bone. Note that the deep trough on the periphery of the trace is not considered taxonomically diagnostic. (4) Schematic cross section through the center of DPC-7401-05 showing shallow depth of penetration into the cortical bone and the asymmetrical peripheral trough. 


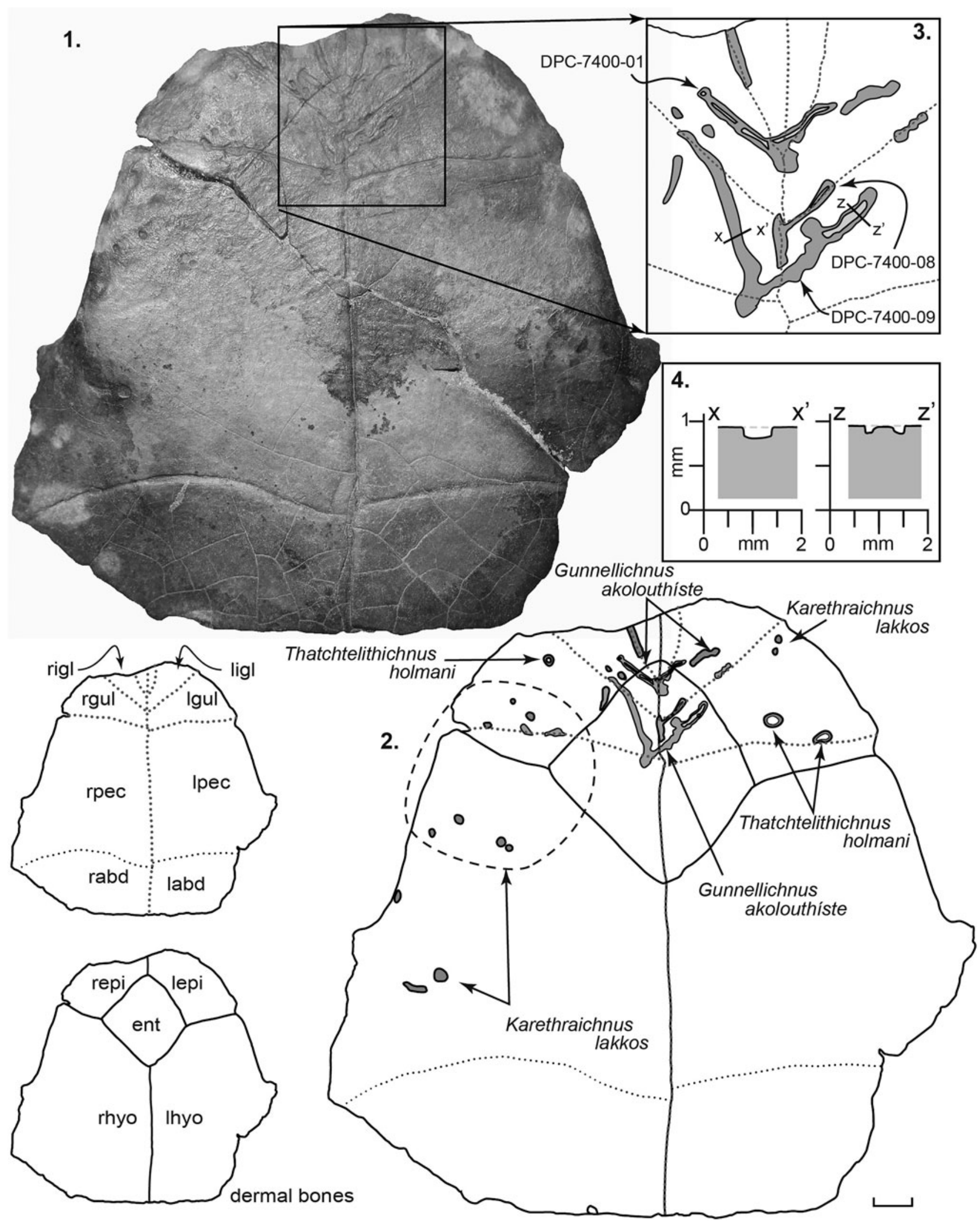

Figure 7. Front part of podocnemid plastron, DPC 7400, preserving the left and right epiplastra, the entoplastron, the right hyoplastron, and part of the left hyoplastron. Inset sketches at bottom left show the distribution of dermal bones and the location of overlying epidermal scutes (not preserved). $r=$ right; $1=$ left; igl $=$ intergular; gul = gular; pec $=$ pectoral; abd = abdominal; ifm = inframarginal; epi $=$ epiplastron; ent $=$ entoplastron; hyo = hyoplastron. $(\mathbf{1})$ Photograph of ventral surface of DPC 7401. (2) Line drawing of the ventral surface of DPC 7401 showing the distribution of traces. Note that darker shading indicates greater depth of penetration. (3) Close-up sketch of the holotype and paratype of Gunnellichnus akolouthiste. (4) Cross sections through the left and right branches of paratype DPC-7400-08. 
cavity shows minute, irregular jags, resulting from brittle deformation" (Mikuláš et al., 2006, p. 119).

Occurrence.-Paleozoic to Pleistocene, global.

Remarks.-A solitary Moghra trace fossil is attributed to Nihilichnus nihilicus (Fig. 2.1, 2.3). This trace fossil, which occurs on the upper (dorsal) surface of a carapace peripheral (DPC 12545), comprises a shallow circular pit showing evidence of the irregular jags and brittle deformation that are the hallmark of $N$. nihiliichnus.

\section{cf. Nihilichnus sp.}

Figure 2.2, 2.4

Remarks. - A cluster of ovoid pits or depressions on the dorsal (lower) surface of DPC 12545 are attributed here to cf. Nihilichnus sp. (Fig. 2.2, 2.4). The ovoid pits are aligned in two distinct lines, oriented at $\sim 40^{\circ}$ from each other. The alignment of the pits and their overall geometry are consistent with type material of $N$. nihilicus (Mikuláš et al., 2006); however, the diagnostic irregular jags are absent, and thus the assignment here is considered tentative. The longer of the two lines consists of six distinct pits that decrease in size and change in shape from rounded rectangular to ovoid as they progress from right to left (Fig. 2.2, 2.4).

Ichnogenus Karethraichnus Zonneveld et al., 2016

Type ichnospecies.-Karethraichnus lakkos Zonneveld et al., 2016.

Other ichnospecies.-Karethraichnus kulindros Zonneveld et al., 2016; Karethraichnus fiale Zonneveld et al., 2016.

Diagnosis. - Circular to subcircular and oval pits and holes bored into bony substrates. The hole may penetrate fully through the substrate or terminate within the substrate as a shallow, bowl-shaped pit or as a deeper shaft with a rounded, blunt, or pointed terminus.

Known occurrence.-Early Eocene of North America; early Miocene of North Africa.

Remarks. - Karethraichnus was established to include circular to subcircular nonpenetrative pits and penetrative holes bored into bony substrata (Zonneveld et al., 2016). The holotype and hypodigm were emplaced in turtle carapace and plastron bone and are interpreted to reflect the activities of parasites rather than postmortem scavengers or synmortem predators (Zonneveld et al., 2016). All specimens occur on surfaces that would have been accessible to parasites, and in many fully penetrative exemplars the host organism exhibited a physiological response to the actions of the parasite by forming an inner bone patch (Zonneveld et al., 2016). Although no evidence of healing was noted on the Moghra material, all Karethraichnus observed in this study occur on surfaces that would have been accessible to parasites while the host animal was alive.
Karethraichnus lakkos Zonneveld et al., 2016

Figures 2.1, 2.3, 3-6

Holotype.-UA-TF140-1, a pit on the ventral surface of a peripheral of the emydid turtle cf. Echmatemys sp., South Pass, Wyoming, United States.

Diagnosis.-Nonpenetrative Karethraichnus with a simple profile and a rounded to flattened, hemispherical terminus.

Occurrence.-Early to middle Eocene of North America; early Miocene of North Africa.

Description. - The size of this ichnotaxon varies from 1.5 to 11 $\mathrm{mm}$ in diameter. The circularity of the traces is also variable, ranging from $0.7 \mathrm{~mm}$ to $10.0 \mathrm{~mm}$ in diameter and including circular, subcircular, and ovoid forms. Finally, the depth of penetration of $K$. lakkos in the Moghra material is notably variable. In general, $K$. lakkos in tortoise material are comparably deep, commonly as deep as they are wide, whereas those in aquatic forms range from deep specimens to those that are quite shallow (width-to-depth ratio ranging from $1: 1$ to $1: 0.2$ ).

Remarks.-The holotype and associated material of Karethraichnus lakkos occur in the carapaces and plastra of the geoemydid turtle cf. Echmatemys sp. collected from fluvial and marginal lacustrine successions in the early Eocene Wasatch Formation, Wyoming. Karenthraichnus lakkos are common on the external surfaces of the plastron and carapaces of a variety of Moghra turtles.

Karethraichnus lakkos are common on both tortoises and podocnemids in the study area. On the tortoise peripheral specimen DPC 12545, three small (2-3 mm diameter) K. lakkos are present (Fig. 2.1, 2.3). Eight K. lakkos occur on the Namibchersus cf. N. namaquensis plastron, all along epidermal sulci (Figs. $3,4)$. Three are visible on the upper surface of the epiplastra along the intergular sulcus, three are on the lower surface of the epiplastra along the intergular sulcus, and one each occurs on the left and right sulci, between the gular and humeral epidermal scutes (Figs. 3, 4).

Karethraichnus lakkos are present on all Erymnochelys analyzed from the study area, invariably on external surfaces. On most turtles, K. lakkos are scattered about the carapace and plastron, most commonly adjacent to epidermal sulci but certainly not limited to those areas. Of the material analyzed, $K$. lakkos are most abundant on specimen DPC 7401 (Figs. 5, 6), where they are present on the hyoplastra, on the epiplastra, and on the boundaries of the entoplastron with the epiplastra and with the right hyoplastron.

Ichnogenus Thatchtelithichnus Zonneveld et al., 2016

Type ichnospecies. - Thatchtelithichnus holmani Zonneveld et al., 2016.

Other ichnospecies.-Ichnogenus is monotypic.

Diagnosis. - As for the type ichnospecies by monotypy. 
Occurrence.-Early Eocene of North America; early Miocene of North Africa.

Remarks.-Thatchtelithichnus are simple ring-shaped traces, analogous to the calcareous shell ichnotaxon Oichnus excavatus (Zonneveld et al., 2016). The validity of Thatchtelithichnus was recently called into question (Wisshak et al., 2019). Although reasons were not provided, these authors interpreted the ichnotaxon as a bioclaustration (an interaction in which a systemic reaction to a parasite by the host organism's bone or tissue results in growth of a gall or spur). Evidence for a gall/bone spur/reaction by the host animal occurs neither in the holotype (Zonneveld and Bartels, 2019) nor in other Paleogene and Neogene examples of this ichnotaxon from several that we have observed (e.g., Collareta et al., 2020). Thus, Thatchtelithichnus is indeed a valid ichnotaxon wherein the tracemaker incised through the outer part of the cortical bone and, in some instances, into the outer part of the trabecular or cancellous bone (Zonneveld et al., 2016; Zonneveld and Bartels, 2019; Collareta et al., 2020).

Thatchtelithichnus holmani Zonneveld et al., 2016 Figures 5.1, 5.2, 7.1, 7.2

Holotype.-UA-TF149-1 on an emydid (cf. Echmatemys sp.) costal bone from the early Eocene Cathedral Bluffs Tongue of the Wasatch Formation, South Pass, Wyoming.

Diagnosis. - Ring-shaped nonpenetrative borings into a bone substrate; central boss or pedestal may be lower than, or at the same level as, bone surrounding the trace.

Occurrence.-Early Eocene of North America; early Miocene of North Africa.

Description.-Originally the ichnogenus Thatchtelithichnus was intended to include two ichnospecies, one in which the central platform was sharply defined and at the same elevation as the surrounding bone and a second wherein the central platform formed a rounded nubbin at a lower elevation than the surrounding, unbored bone (Zonneveld et al., 2016). Before publication, these two ichnospecies were lumped together as T. holmani, and the diagnosis of this ichnospecies includes both endmember forms as well as all gradations in between (Zonneveld and Bartels, 2019).

The Moghra traces are remarkably similar to the type material identified on emydid turtles collected from lacustrine strata in the Wasatch Formation, Wyoming. Although the holotype and hypodigm are quite small (1.5-2 $\mathrm{mm}$ in diameter), Thatchtelithichnus holmani from the type area range widely in size (1.5-7 $\mathrm{mm}$ in diameter). Those from Moghra fall within the upper end of this range (Figs. 5, 7). Similar to the Wasatch traces, the Moghra T. holmani occur solely on the ventral surface of plastron bone elements of aquatic turtles.

Remarks. - The prevalence of this ichnotaxon on aquatic turtles suggests a similar tracemaker; however, it is worth noting that similar ring-shaped traces have also been reported on a Cretaceous dinosaur long bone (Bader et al., 2009). It was noted in the Wasatch Formation material that although the trace is rare overall, when it does occur, multiple traces can be found clustered on a single host animal, most of a similar size and depth (Zonneveld et al., 2016). Its prevalence on aquatic turtle shell, particularly on the ventral side of the plastron, supports the hypothesis that these traces represent the activity of larval parasites that settled on their substrate at the same approximate time.

\section{Ichnogenus Gunnellichnus new ichnogenus}

Type ichnospecies.-Gunnellichnus moghraensis new ichnospecies.

Other ichnospecies.—Gunnellichnus akolouthiste new ichnospecies.

Diagnosis.-Shallow, wide depressions on the external surface of cortical bone; typically many times wider than deep; outer margin edge smoothly scalloped to gently undulose, rarely straight; marginal troughs deeper than center of trace variably present; width-to-depth ratio >10:1, commonly exceeds 100:1

Known occurrence.-Early Miocene of northern Egypt; early to middle Eocene of western North America.

Etymology.-After Gregg F. Gunnell, friend, mentor, and colleague, in acknowledgement of his four decades of exceptional contributions to Cenozoic vertebrate paleontology.

Remarks.-The observed dimensions of Gunnellichnus are variable, ranging from tiny patches $2 \mathrm{~mm}$ wide and approximately twice as long to large examples $1-2 \mathrm{~cm}$ wide and $3-7 \mathrm{~cm}$ long (Figs. 5-7). All examples penetrate only the outer cortical surface of the bone and are invariably less than $1 \mathrm{~mm}$ deep. The outer rim of the trace can be quite irregular but can also be smooth and scalloped.

Two species of Gunnellichnus are named, and it is not anticipated that others will be added to this ichnogenus. Gunnellichnus is unlike other bone-hosted ichnotaxa. Palaeomycelites, Osedacoides, Clavichnus, Cuniculichnus, and Osteichnus all penetrate through the outer cortical bone into internal spongy bone and are deeper than they are wide (Bystrow, 1956; Karl et al., 2012; Höpner and Bertling, 2017). Sulculites consist of smooth, straight to curved, narrow, nonbranching grooves in bone (Vialov and Nessov, 1974) and have a much greater depth-to-width ratio than Gunnellichnus. Similarly, Cubiculum and Karethraichnus penetrate more deeply into the bone than Gunnellichnus (typically into the inner spongy bone), Cubiculum is ovoid to lozenge-shaped, and Karethraichnus is generally circular to subcircular (Roberts et al., 2007; Zonneveld et al., 2016). Arguably, Osteocalis is most similar in terms of dimensions to Gunnellichnus; however, Osteocalis is defined by closely spaced arcuate grooves (Roberts et al., 2007), a feature absent in Gunnellichnus.

Gunnellichnus moghraensis new ichnospecies Figures 5.1, 5.2, 6.1, 6.2 
Holotype.-The holotype, DPC 7401-01, occurs on a plastron of Erymnochelys (Figs. 5, 6). The trace occurs solely on the left hyoplastron (Figs. 5.1, 5.2, 6.1, 6.2).

Diagnosis.-Shallow, wide, millimeter to submillimeter depth, nonpenetrative borings into the surface of cortical bone, much wider than deep; outer margin edge smoothly scalloped to gently undulose, width-to-depth ratio $>25: 1$, commonly exceeds 100:1.

\section{Occurrence.-Wadi Moghra, early Miocene, Egypt.}

Description.-The observed depth to which this trace penetrates into bone surfaces ranges from 0.05 to $0.80 \mathrm{~mm}$, whereas the surface expression (areal coverage) of observed specimens ranges from $0.25 \mathrm{~cm}^{2}$ to $12.5 \mathrm{~cm}^{2}$ (Figs. 5.1, 5.2, 6.1-6.3). All G. moghraensis observed on DPC 7401 are elongate ( 26 times longer than wide) lesions with axes approximately parallel/subparallel to each other $\left(\sim 77^{\circ}, 84^{\circ}, 89^{\circ}\right.$, and $90^{\circ}$ from the cranial-caudal axis of the plastron). The floor, or basal surface, of G. moghraensis is rough and uneven, with evidence of neither scratch marks nor gnaw marks.

A curious aspect of the holotype and most other specimens of G. moghraensis is the marginal trough that forms part of the periphery of the trace. DPC-7401-05 illustrates this character particularly well. Throughout most of the trace, bone penetration is particularly shallow $(<0.1 \mathrm{~mm})$, with only the outermost layer of the bone removed; however, several deeper $(\sim 0.2-0.7 \mathrm{~mm})$ marginal troughs extend along most of the periphery of the trace. Due to the inconsistent presence of this character, we do not, currently, include it as part of the diagnosis of G. moghraensis. With identification and examination of additional material of G. moghraensis, we anticipate that the significance and occurrence of this aspect will be clarified.

Etymology.-After the type locality at Wadi Moghra.

Remarks.-Gunnellichnus moghraensis in this study are limited in occurrence to the bottom shells (ventral surface of plastron) of aquatic turtles, a location that would have protected the borer from exposure even when the host organism left the water. Minute, irregularly spaced circular pits $(0.1-0.7 \mathrm{~mm}$ in diameter) occur in DPC 7401-02. These are not diagnostic of this ichnotaxon, and it is not implied that any or all of these were made by a parasite. Indeed, some or all may simply be areas where the trace fossil penetrated through to natural voids within the bone. In some cases (e.g., DPC 7401-02 and DPC 7401-06), G. moghraensis appear to have been formed around other bone borings.

\section{Gunnellichnus akolouthiste new ichnospecies} Figure 7.1-7.3

2001 Linear excavations, Hutchison and Frye, p. 13, fig. 1.

Holotype.-The holotype, DPC 7400-01, occurs on a plastron of Erymnochelys (Fig. 7). The trace occurs centrally, branching outward from the central intergular suture. The two paratypes occur slightly posteriorly to the holotype (Fig. 7):
DPC 7400-08 branching from the sulcus between the gular scutes, and DPC 7400-09 initiating on a point on the sulcus between the right branching and a point between the right gular and right pectoral scutes and branching forward from there (Fig. 7).

Diagnosis.-Shallow, narrow, nonpenetrative, simply branching borings into the surface of cortical bone, wider than deep; outer margin edge scalloped or gently curved to gently undulose, width-to-depth ratio typically $<25: 1$.

Occurrence.-Early Miocene, Wadi Moghra, Egypt.

Description.-Gunnellichnus akolouthiste form narrow, sinuous, shallow lesions or grooves, most commonly following epidermal sulci and dermal bone sutures (Fig. 7.17.3). The depth of penetration ranges from 0.05 to $0.50 \mathrm{~mm}$, and the width of individual occurrences ranges from 1.2 to $2.90 \mathrm{~mm}$. They are typically much longer than they are wide. The floor of the trace is typically rough and uneven, and in some cases, it may have a central raised ridge (i.e., a ridge of bone not bored as low as the trace periphery).

Etymology.-From the Greek akolouthiste (romanization of

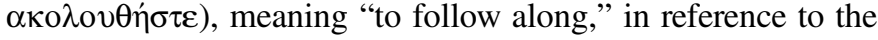
holotype and paradigm following epidermal suture margins and dermal bone margins in the host taxon.

Remarks.-To date, Gunnellichnus akolouthiste has been observed on a single Erymnochelys plastron (DPC 7400) from the Moghra Formation. The ichnofossil consists of a dense network of traces that branch in a forward direction (Fig. 7.17.3). The holotype is centered on the midline of the plastron near the junction of the gular and intergular scutes (Fig. 7.3). Most other occurrences branch away from the midline, and thus, it appears that the parasite gained access to the bone surface beneath the epidermal scutes by penetrating through epidermal sulci. Trace fossils identical to Gunnellichnus akolouthiste occur on the carapace of the Eocene turtle Notomorpha (formerly Baptemys) garmanii (Cope, 1872) from the Lost Cabin Member of the Wind River Formation of Wyoming (Hutchison and Frye, 2001). Additional traces referable to $G$. akolouthiste occur on dermatemydid and geoemydid turtle carapace and plastron elements from the early to middle Eocene Wasatch and Green River formations in the South Pass area of Wyoming. As on the Moghra material, G. akolouthiste on the South Pass material commonly follow epidermal suture margins.

\section{Discussion}

There remains significant contention among ichnologists regarding substrate as an ichnotaxobase (e.g., Bertling et al., 2006; Zonneveld et al., 2016; Höpner and Bertling, 2017; Donovan and Ewin, 2018). We follow several recent contributions that argue convincingly that bone is a unique substrate that provides both benefits and challenges to boring organisms and that these benefits and challenges differ significantly from those of other substrates (Zonneveld et al., 2016; Höpner and Bertling, 
2017; Wisshak et al., 2019; Zonneveld and Bartels, 2019). Bone borers must penetrate through a complex composite medium consisting of different layers of dense and cancellous hydroxyapatite $\left(3 \mathrm{Ca}_{3}\left(\mathrm{PO}_{4}\right)_{2}-\mathrm{Ca}(\mathrm{OH})_{2}\right)$ and, if the animal is still living, various layers of soft or keratinous epidermal layers, blood vessels, cartilage, and collagen (Zonneveld et al., 2016). Clearly, bone, particularly living bone, provides unique challenges to tracemakers. It is not a typical lithic substrate and should be considered differently from rock, wood, invertebrate shell, or unconsolidated sediment (Zonneveld et al., 2016; Höpner and Bertling, 2017; Wisshak et al., 2019; Zonneveld and Bartels, 2019).

Bone borings from the Moghra Formation occur in both terrestrial tortoises and aquatic turtles. In almost all cases, the borings identified in turtle carapace and plastron (e.g., Karethraichnus, Thatchtelithichnus, Gunnellichnus) are interpreted as having been emplaced while the host animal was alive. Trace fossils assigned herein to Nihilichnus on a carapace fragment of a tortoise are an exception and may have been emplaced either during a predation attempt while the host organism remained alive or by a scavenger after the host organism had died.

The following discussion regarding possible tracemakers is separated by host organism since the different turtle hosts had distinct environmental preferences and distinct possible tracemakers. Of note, Karethraichnus lakkos was observed in both terrestrial tortoises and aquatic turtles. Typical of many traces, multiple tracemakers may make similar traces, and the tracemaker of $K$. lakkos in the two different host taxa are interpreted to be different.

Inferred tracemakers: tortoises. - Nihilichnus (N. nihilicus and cf. Nihilichnus isp.) occur on the tortoise carapace peripheral (DPC-12545; Fig. 2). A solitary N. nihilicus occurs on the dorsal surface of the bone (Fig. 2.1, 2.3) while a cluster of cf. Nihilichnus isp., occurring in two distinct, slightly curved linear trends (Fig. 2.2, 2.4), is present on the ventral surface. The solitary $N$. nihilicus of the upper surface is interpreted to have been emplaced by an upper canine of a mammalian carnivore while the curved lines attributed to cf. Nihilichnus isp. are interpreted to record the cheek teeth (canine, premolars, and molars) of the same organism. The longer line of cf. Nihilichnus isp. displays a decreasing-in-size trend from right to left, consistent with mammalian carnivore mandibular dentition. The lack of irregular jags, which is diagnostic of $N$. nihilicus, is interpreted to reflect post-emplacement physical reworking of the tortoise carapace peripheral, a hypothesis supported by the poorly sorted sand matrix still present within some of the traces. It is impossible to establish whether these Nihilichnus were emplaced during an attempt at predation while the host organism remained alive or by scavenging of a dead carcass. It is worth noting that two distinct bite marks, represented by the two distinct linear trends of cf. Nihilichnus sp., occur on the carapace peripheral but did not penetrate through the peripheral and would not have been life-threatening to the tortoise.

Karethraichnus lakkos are common on both the tortoise carapace peripheral (DPC 12545) and the anterior portion of a tortoise plastron (DPC 6443) discussed herein (Figs. 2-4).
These are interpreted to be borings emplaced by an invertebrate ectoparasite. Nonaquatic terrestrial turtles such as tortoises can be colonized by a variety of arthropods, including dipterans and ixodid arachnids (e.g., Harbinson, 1937; Baker, 2007; Mitchell, 2007). Dipteran larvae have been noted on injured or abraded areas of tortoise shells (Woodbury and Hardy, 1948; Woodbury, 1952). Ixodid arachnids (ticks) and mites are perhaps the most common parasites on tortoises (Harbinson, 1937; Ghirotti and Mwanaumo, 1989; Fielden and Rechav, 1994; Grover and Defalco, 1995; Horak et al., 2006a, b). Although these parasites are most prevalent on soft tissue, they also occur on the shell, particularly at the site of an injury or at the sutures between scutes (Ryckman and Kohls, 1962; Coombs, 1973, 1974, 1977).

Ixodid arachnids are the most likely parasites to have formed the K. lakkos on Moghra tortoises. Ticks more commonly attach on the inner lip of the plastron and carapace than on external surfaces (Simmons and Burridge, 2000), likely because external surfaces are prone to physical abrasion against the ground and against branches and twigs as the host animal moves through its habitat. Although we could find no record of bone damage caused by tortoise ticks, ticks have been reported to occupy pits in the carapace and plastron of the neotropical terrestrial geoemydid genera Rhinoclemys and Callopsis (Fairchild, 1943; Ernst and Ernst, 1977). In both taxa, the pits are most common at the boundaries of epidermal scutes (Mittermeier, 1971; Ernst and Ernst, 1977), and they are circular to subcircular and up to $6 \mathrm{~mm}$ in diameter and up to $4 \mathrm{~mm}$ deep (Mittermeier, 1971; Ernst and Ernst, 1977). It is thought that the ticks bore through the epidermis and into the dermal bone, employing either a histolytic secretion or microorganism (fungal or bacteria) that attacks the shell at the site of the attachment wound (Mittermeier, 1971; Ernst and Ernst, 1977). Although Fairchild (1943) did not identify the ticks present, Ernst and Ernst (1977) noted that four species of the genus Ambylomma were involved, which is a common parasite on African tortoises (Ghirotti and Mwanaumo, 1989; Fielden and Rechav, 1994; Horak et al., 2006a, b).

It is worth noting that $K$. lakkos on tortoise shells may not have had a single tracemaker. Sarcophagid dipterans ("flesh flies") occur on the skin and shells of terrestrial turtles and tortoises (Peters, 1948; Jackson et al., 1969; Mitchell, 2007). Although these flies have not been observed to bore through either the epidermal or dermal layer, they may opportunistically occupy a tick-created pit (Knipling, 1937; Peters, 1948; King and Griffo, 1958; Jackson et al., 1969; Greene, 1983; Jacobson, 1994; Mitchell, 2007), and bacterial infections that result may modify or expand the pit.

Inferred tracemakers: aquatic turtles.-Modern freshwater turtles carry a number of subcutaneous parasites, including platyhelminths, hirudinead annelids (leeches), and ixodid arachnids (ticks) (e.g., Ernst and Ernst, 1977; Graham et al., 1997; Baker, 2007). In addition, a variety of fungal and bacterial infections may occur under the epidermal layer and affect dermal bone integrity (e.g., Lovich et al., 1996; Garner et al., 1997; Ramaglia et al., 2004).

Karethraichnus lakkos are, by far, the most common trace observed on the shells of aquatic Moghra turtles (Figs. 5-7). 
Freshwater turtles can be infected by a number of platyhelminth taxa. Although these are more commonly parasites of the intestines, several forms can occur subcutaneously (Mitchell, 2007). Both trematodes (e.g., Gyrodactylus spp.) and cestodes (e.g., Diphyllobothrium erinacei [Rudolphi, 1819] and Spirometra mansonoides [Mueller, 1935]) been observed on the skin and shells of aquatic turtles (Johnson et al., 1998; Harris et al., 2004; Mitchell, 2007).

Hirudinead annelids (leeches) are particularly common parasites on turtles in freshwater systems, particularly lakes and ponds (Ernst and Ernst, 1977; Graham et al., 1997). Leeches are considered the likeliest parasite to have created the $K$. lakkos on Moghra aquatic turtles. In addition to soft tissue near the neck and limb sockets, leeches attach to both the carapace and plastron (e.g., MacCulloch, 1981; Graham et al., 1997; Siddall and Gafney, 2004; Readal et al., 2008; Fediras et al., 2017). Shell-hosted leeches are particularly common on the plastron, where they find protection from desiccation when the host turtle leaves the water (Vogt, 1979; Fediras et al., 2017). Placobdella ornata (Verrill, 1872) and $P$. costata (Müller, 1846) have been observed to show a preference to sulci (epidermal scute borders), areas with damaged or missing epidermal scutes, or areas of bone damage (Hulse, 1976; Ernst and Ernst, 1977; Siddall and Gafney, 2004; Ayres and Alvarez, 2008; Bielecki et al., 2012; Fediras et al., 2017). Leech parasitism is much higher in bottom-dwelling turtles than in turtles that bask subaerially (Hulse, 1976; Ryan and Lambert, 2005; McCoy et al., 2007; Readal et al., 2008; Parren, 2013). Leech attachment localities have the potential to affect/modify the dermal bone of the carapace and plastron (Siddall and Gafney, 2004), and they may form circular pits, similar to K. lakkos. Leech salivary secretions likely contribute to bone decalcification and digestion of connective tissues (Siddall and Gafney, 2004). Both Placobdella ornata and $P$. costata can penetrate bony tissues to obtain blood meals (Siddall and Gafney, 2004; Readal et al., 2008).

It remains uncertain which parasite created the Thatchtelithichnus holmani present on several aquatic turtle plastra observed in this study. Modern studies have identified no parasite that leaves a ring-shaped trace on its host. The circular shape of $T$. holmani is consistent with the shape of leech anterior suckers, so these traces may be the leech attachment traces, possibly by a taxon distinct from those that created other ichnotaxa. However, this hypothesis remains conjectural until more research on turtle shell parasites and their effects on the host organisms is completed. Regardless, this trace fossil has now been recognized on aquatic turtle fossils in the Eocene of North America, Pliocene of Europe, and Miocene of North Africa (Zonneveld et al., 2016; Collareta et al., 2020, and material herein) suggesting that the parasite taxon / taxa that make this trace is widely distributed.

Two new ichnospecies within one ichnogenus are identified herein. Gunnellichnus moghraensis and G. akolouthiste occur on the plastra of Erymnochelys. Both ichnotaxa shallowly penetrate the outer surface of the bone (cortical layer) and are irregular in overall shape and size. These ichnotaxa are herein attributed to either fungus or bacteria, or to the combined effects of both. Shell disease, often referred to as shell rot, septicemic cutaneous ulcerative dermatitis (SCUD), or ulcerative shell disease (USD), is a type of osteomyelitis that occurs in many populations of aquatic turtles, particularly those in areas of poor nutrition, environmental degradation, or persistent damp conditions (e.g., Lovich et al., 1996; Garner et al., 1997; Arvy and Fertard, 2002; Barnett, 2003; Ramaglia et al., 2004). This disease can result in extensive, amorphic shell dissolution and has been attributed to fungal and bacterial infections (Kaplan, 1957; Wallach, 1975; Frye, 1991; Lovich et al., 1996; Garner et al., 1997; Hutchison and Frye, 2001; Rose et al., 2001; Ramaglia et al., 2004; Sinn, 2004; Lafortune et al., 2005; Rothschild et al., 2012, 2013). Shell disease routinely results in large amorphous patches of damage on the external surface of the shell and complete shell dissolution in large parts of a turtle's shell (our observations as well as discussion in the preceding references). Extensive damage and shell dissolution were not noted in the Moghra material. It is doubtful that the discrete patches of etched or corroded shell that characterize both $G$. moghraensis and G. akolouthiste are indicative of early stages of shell disease. We have analyzed numerous modern turtle plastra and carapaces characterized by incipient and extensive SCUD/USD modification. SCUD/USD patches invariably have irregularly penetrating bases and commonly breach through the shell, and in no SCUD/USD specimen have we observed the shallow etching with the peripheral trough or canal-like modification noted in the Moghra material. Indeed, SCUD/USD bone modification exhibits highly irregular bone depth modification and amorphic irregular boundaries with unaffected bone, very dissimilar to Gunnellichnus moghraensis and $G$. akolouthiste. Finally, it is also worth noting that both $G$. akolouthiste and specimens with extensive shell damage due to USD or SCUD occur in Eocene strata of Wyoming with no gradational forms having been observed to date (JPZ, unpublished observations).

Ethological implications of host taxa and parasites.-Abundant Karethraichnus lakkos on tortoise carapace and plastron bone indicates a moderately heavy parasite load on Moghra tortoises. All modern tortoise taxa host ticks, most commonly of the genus Amblyomma (e.g., Ghirotti and Mwanaumo, 1989; Waller et al., 1989; Fielden and Rechav, 1994; Grover and Defalco, 1995; Horak et al., 2006a, b), with no clear preference for environment noted. The occurrence of $K$. lakkos on Moghra tortoises provides evidence that tick parasitism on tortoises goes back to at least the beginning of the Neogene.

Abundant, and moderately diverse, boring ichnotaxa on some Erymnochelys, an aquatic pleurodiran turtle, provides invaluable evidence regarding the host taxon's ecology. Karethraichnus lakkos, Thatchtelithichnus holmani, Gunnellichnus moghraensis, and G. akolouthiste were all noted on two of the Erymnochelys plastra (DPC-7400 and DPC-7401). This implies a relatively high parasite load, consistent with a bottom-dwelling turtle taxon in more stagnant water settings.

Reduced parasite loads, particularly of leeches, platyhelminths, and bacteria, have been associated with increased basking times (Boyer, 1965; Moll and Legler, 1971; Auth, 1975; Vogt, 1979; Lindemann, 1996, 1999; Ryan and Lambert, 2005), although colonization by ticks and dipterans increases with increased time out of the water. Studies have also illustrated within-species variations in ectoparasite load related to environmental preference (e.g., Reshke, 2009). Painted turtles 
(Chrysemys picta [Schneider, 1783]) from swamp environments were observed to have two to three times more leeches than $C$. picta from more open-water settings (Reshke, 2009). This may explain abundant borings on DPC 7400 and DPC 7401 relative to the sparsely distributed borings on NHMUK 2927, the holotype of "Podocnemis" aegyptiaca (now Erymnochelys cf. E madagascariensis). The very few borings, limited to a few $K$. lakkos on NHMUK 2927 (including a few on the carapace), may reflect a greatly reduced leech load and increased tick parasitism with time spent out of the water.

Depositional environment.-The material discussed herein was all surface collected, with minimal data recorded on original depositional environment. Of note, both DPC 12545 (Testudininei indeterminate) and DPC 6443 (Namibchersus cf. $N$. namaquensis) retain similar patches of matrix consisting of a moderately to poorly sorted, coarse-grained quartz-dominated litharenite. It is thus postulated that both may have eroded from the same fluvial deposit and may have been transported some distance from the environment in which they lived. Medium-grained sandstone is also preserved within Karethraichnus lakkos and on the interhyoplastral sutures of DPC 7400, a lithology inconsistent with the paludal/stagnant-water setting inferred for this taxon. Thus, it is interpreted that all the turtle material was fluvially reworked before final deposition.

\section{Conclusions}

Numerous trace fossils occur on turtle shell bones (carapace and plastron fragments) from the early Miocene Moghra Formation, Wadi Moghra, Egypt. Tortoises and turtles differ significantly from other vertebrates in that they have large expanses of dermal bone shielded by a thin epidermal layer. All invertebrate traces observed in this study are interpreted to be the result of parasite activity while the animals were alive rather than as the result of postmortem scavenging.

Tortoise bones include a low-diversity assemblage of traces attributed to both vertebrates and invertebrates. Karethraichnus lakkos, the sole invertebrate ichnotaxon identified on tortoises, is interpreted to preserve combined feeding/attachment traces of ixodid ticks. Some of the larger K. lakkos may also indicate enlargement by dipteran fly larvae. Both dipterans and ixodid ticks are common parasites on turtles. The presence of $K$. lakkos on Moghra tortoise fossils indicates that this parasitic relationship extends back to at least the early Miocene.

The vertebrate bite trace Nihilichnus nihilicus also occurs on tortoise shell at Moghra. The single carapace peripheral on which this was observed exhibits a single tooth mark on the dorsal surface and a pair of aligned tooth-mark sets on the ventral surface. This is interpreted to be evidence of postmortem scavenging rather than predeath predation. Certainly, the carapace peripheral exhibits surface damage but was not crushed or broken by the scavenger.

Aquatic turtles at Moghra have, overall, a much higher proportion of invertebrate borings than do tortoises. Karethraichnus lakkos and Thatchtelithichnus holmani traces on aquatic turtles are interpreted to reflect a combination of leech and trematode parasitism. These traces are variable in size and placement on the shell. In general, they are much more common on the plastron than on the carapace, and they are much more prevalent on the boundaries between epidermal scutes (sulci) or in areas where the scutes were damaged or shed.

Two new ichnospecies within one ichnogenus (Gunnellichnus moghraensis and G. akolouthiste) are interpreted to reflect bacterial and/or fungal degradation of the basal surface of the plastron. The host turtle occupied an environment persistently moist enough that the fungal and bacterial infections did not dry out. The limited penetration of Gunnellichnus on the plastron bones indicates that the infection was not life threatening.

Turtle carapace and plastron bone-hosted trace fossils provide evidence of organismal interaction at Moghra during the early Miocene. Further, the nature and distribution of invertebrate borings on these turtle shells provide intimations as to ethological preferences and variability of these extinct turtles.

\section{Acknowledgments}

This study is the direct result of observations made by Gregg F. Gunnell and brought to the attention of the lead author. During the course of this study, Gregg passed away, to the great loss of our discipline and to those of us with whom he shared his love of life, both present and past. You are missed, Gregg.

C. Riddle is thanked for her help with the Duke Fossil Primate Centre collections and for providing locality information and graciously fielding numerous questions regarding the DPC herps. P. Brewer, J. Darrell, N. Sandadomingo Aquilar, and S. Chapman are thanked for facilitating our visit and providing access to fossils in the Natural History Museum in London, England. Research travel was supported by an NSERC Discovery Grant to JPZ and through DPC funding to GFG.

\section{References}

Abdel Gawad, M. K., 2011, Geological and Paleoecological Aspects of the Moghra Fossil Mammals, north Western Desert, Egypt: M.Sc. Thesis, Cairo, Cairo University, $211 \mathrm{p}$.

Abdel Gawad, M. K., 2016, Crocodylian and Testudines paleontological and paleoenvironmental studies of the early Miocene sediments, Qattara Depression, north Western Desert, Egypt [Ph.D. dissertation]: Giza, Cairo University, $245 \mathrm{p}$.

Abdel Gawad, M.K., Miller, E.R., Hamdan, M.A., Ali, S.M., El-Sharkawy, M.A., and El-Barkooky, A.N., 2010, Stratigraphic distribution of fossil mammals in the early Miocene Moghra Formation, north Western Desert, Egypt, in Proceedings, 10th International Conference on the Geology of the Arab World: Cairo, Cairo University, p. 52-53.

Abdel Gawad, M.K., Miller, E.R., Hamdan, M.A., El-Barkooky, A.N., and El-Sharkawy, M.A., 2012, Vertebrate and geological signatures on the construction of Moghra Formation, north Western Desert, Egypt: Journal of Vertebrate Paleontology, v. 32, p. 54.

Abdel Gawad, M., Sertich, J., Sallam, H., Miller, E., El-Barkooky, A., Hamdan, M., and Gunnell, G.F., 2014, Reptilian fauna from the early Miocene of Wadi Moghra, Western Desert, Egypt: Journal of Vertebrate Paleontology, Program and Abstracts, 74th Annual Meeting of the Society of Vertebrate Paleontology, p. 77.

Abdel Gawad, M. K., Hirayama, R., Chapman, S., El Barkooky, A. N., Hamdan, M. A., Miller, E. R., Sallam, H. M., and Gunnell, G. F., 2018, New materials on the Testudines remains from early Miocene, Wadi Moghra, north Western Desert, Egypt: Abstracts of the Turtle Evolution Symposium, Tokyo, Japan, p. 7-10.

Andrews, C.W., 1899, Fossil mammals from Egypt: Geology Magazine, new ser., v. 4, p. 481-484.

Andrews, C.W., 1900, On a new species of Chelonian (Podocnemis aegyptica) from the lower Miocene of Egypt: Geological Magazine, new ser., v. 7, p. 1-3.

Andrews, C.W., 1901, Preliminary note on some recently discovered extinct vertebrates from Egypt, part II: Geological Magazine, v. 8, p. 440-444. 
Andrews, C.W., 1904, Note on the gigantic land tortoise (Testudo ammon Andrews) from the Upper Eocene of Egypt: Geological Magazine, new ser., v. 1 , p. 527-530.

Andrews, C.W., 1905, Notes on some new Crocodilia from the Eocene of Egypt: Geological Magazine, new ser., v. 2, p. 481--484.

Arvy C., and Fertard B., 2002, Pathologie des tortues: étude synthétique: Bulletin de la Société Herpétologique de France, v. 100, p. 1-152.

Auffenberg, W., 1974, Checklist of land tortoises (Testudinidae): Bulletin of the Florida State Museum, v. 18, p. 121-251.

Auffenberg, W., 1981, The fossil turtles of Olduvai Gorge, Tanzania, Africa: Copeia, v. 3, p. 509-522.

Auth, D.L., 1975, Behavioral ecology of basking in the yellow-bellied turtle, Chrysemys scripta scripta (Schoepff): Bulletin of the Florida State Museum Biological Sciences, v. 20, p. 1-45.

Ayres, C., and Alvarez, A., 2008, On the presence of Placobdella sp. leeches on Emys orbicularis: Acta Biologica Universitatis Daugavpiliensis, v. 8, p. 53-55.

Bader, K.S., Hasiotis, S.T., and Martin, L.D. 2009, Application of forensic science techniques to trace fossils on dinosaur bones from a quarry in the Upper Jurassic Morrison Formation, northeastern Wyoming: Palaios, v. 24, p. 140 158.

Baker, D.G., ed., 2007, Flynn's Parasites of Laboratory Animals (second edition): Ames, Iowa, Blackwell, $813 \mathrm{p}$.

Barnett S., 2003, Shell infections: when there are chinks in the armor: Terrapin Tales, October, p. 1-8.

Batsch, A.J.G.K., 1788, Versuch einer Anleitung zur Kenntniss und Geschichte der Thiere und Mineralien: für akademische Vorlesungen entworfen, und mit den nöthigsten Abbildungen versehen: Jena, Akademischen Buchhandlung, $528 \mathrm{p}$.

Behrensmeyer, A.K., 1978, Taphonomic and ecologic information from bone weathering: Paleobiology, v. 4, p. 150-162.

Behrensmeyer, A.K., Western, D., and Dechant Boaz, D.E., 1979, New perspectives in vertebrate paleoecology from a recent bone assemblage: Paleobiology, v. 5, p. 12-21.

Bell, T., 1828, Descriptions of three new species of land tortoises: Zoological Journal, v. 3, p. 419-421.

Bertling, M., et al., 2006, Names for trace fossils: a uniform approach: Lethaia, v. 39 , p. $265-286$.

Bielecki, A., Cichocka, J.M., Jablonski, A., Jelen, I., Ropelewska, E., Biedunkiewicz, A., Terlecki, J., Nowakowski, J.J., and Szlachciak, J., 2012, Coexistence of Placobdella costata (Fr. Mûller, 1846) (Hirudinida: Glossiphoniidae) and mud turtle Emys orbicularis: Biologica v. 67, p. 1-8.

Boyer, D.R., 1965, Ecology of the basking habit in turtles: Ecology, v. 46, p. $99-118$.

Brett, C.E., 1985, Tremichnus: a new ichnogenus of circular-parabolic pits in fossil echinoderms: Journal of Paleontology, v. 59, p. 625-635.

Britt, B.B., Scheetz, R.D., and Dangerfield, A., 2006, A suite of dermestid beetle traces on dinosaur bone from the Upper Jurassic Morrison Formation, Wyoming, USA: Ichnos, v. 15, p. 59-71.

Bromley, R.G., 1981, Concepts in ichnology illustrated by small round holes in shells: Acta Geològica Hispànica, v. 16, p. 55-64.

Bromley, R.G., 1993, Predation habits of octopus past and present and a new ichnospecies, Oichnus ovalis: Bulletin of the Geological Society of Denmark, v. 40, p. 167-173.

Bystrow, A.P., 1956, On the damage caused by fungi on the skeletal elements of fossil animals: Leningrad University Vestnik Seria Geologii i Geographii, v. 11 , no. 6, p. 30-46. [in Russian]

Cabral, U.G., Riff, D., Kellner, A.W.A., and Henriques, D.D.R., 2011, Pathological features and insect boring marks in a crocodyliform from the Bauru Basin, Cretaceous of Brazil: Zoological Journal of the Linnean Society, v. 163, p. S140-S151.

Collareta, A., Casati, S., Zuffi, M.A.L., and Di Cencio, A., 2020, First authentic record of the freshwater turtle Mauremys from the upper Pliocene of Italy, with a new occurrence of the rarely reported ichnotaxon Thatchtelithichnus holmani: Carnets de Geologie, v. 20, p. 301-313.

Coombs, E.M., 1973, Desert Tortoise, Gopherus agassizii, Study: Progress Report, Summer 1973 in the Beaver Dam Wash Area: on file at United States Department of the Interior, Bureau of Land Management, Dixie Resource Area, St. George, Utah, 27 p.

Coombs, E.M., 1974, Utah Cooperative Desert Tortoise Study (Gopherus agassizii): on file at United States Department of the Interior, Bureau of Land Management, $17 \mathrm{p}$.

Coombs, E.M., 1977, Wildlife observations of the hot desert region, Washington County, Utah, with emphasis on reptilian species and their habitat in relation to livestock grazing: Report from the Utah Division of Wildlife Resources: on file at United States Department of the Interior, Bureau of Land Management, Dixie Resource Area, St. George, Utah, $210 \mathrm{p}$

Cope, E.D., 1865, Third contribution to the herpetology of tropical America: Proceedings of the Academy of Natural Sciences of Philadelphia, v. 17, p. $185-198$.
Cope, E.D., 1868, On the origin of genera: Proceedings of the Academy of Natural Sciences of Philadelphia, v. 20, p. 242-300.

Cope, E.D., 1872, On a new genus of Pleurodira from the Eocene of Wyoming Proceedings of the American Philosophical Society, v. 12, p. 472-477.

Cruikshank, A.R.I., 1986, Archosaur predation on an East African Middle Triassic dicynodont: Palaeontology, v. 29, p. 415-422.

Dacqué, E., 1912, Die fossilen Schildkröten Aegyptens: Geologische und Paläontologische Abhandlungen, v. 14, p. 275-337.

de Lapparent de Broin, F., 2001, The European turtle fauna from the Triassic to the Present: Dumerilia, v. 4, p. 155-216.

de Lapparent de Broin, F., 2003a, Neochelys sp. (Chelonii, Erymnochelyinae), from Silveirinha, early Eocene, Portugal: Ciências da Terra, v. 15, p. 117 132.

de Lapparent de Broin, F., 2003b, Miocene Chelonians from southern Namibia: Memoir of the Geological Survey of Namibia, v. 19, p. 67-102.

Donovan, S.K., and Ewin, T.A.M., 2018, Substrate is a poor ichnotaxobase: Swiss Journal of Palaeontology, v. 137, p. 103-107.

Edinger, E.N., and Risk, M.J., 1994, Oligocene-Miocene extinction and geographic restriction of Caribbean corals: roles of turbidity, temperature, and nutrients: Palaios, v. 9, 576-579.

Ekdale, A.A., Bromley, R.G., and Pemberton, S.G., 1984, Ichnology: The use of trace fossils in sedimentology and stratigraphy: Tulsa, Oklahoma, SEPM Short Course no. 15, $317 \mathrm{p}$.

El-Khashab, B., 1977, Some Studies on Egyptian Vertebrate Fossils: Cairo, Geological Survey of Egypt, 39 p.

Ernst, C.H., and Ernst, E.M., 1977, Ectoparasites associated with neotropical turtles of the genus Callopsis (Testudines, Emydidae, Batagurinae): Biotropica, v. 9, p. 139-142.

Fairchild, G.B., 1943, An annotated list of the bloodsucking insects, ticks and mites known from Panama: American Journal of Tropical Medicine and Hygiene, v. 23, p. 569-591.

Fediras, S., Rouag, R., Ziane, N., Olivier, A., Béchet, A., and Benyacoub, S., 2017, Prevalence of Placobdella costata (Fr. Mûller, 1846) (Hirudinida: Glossiphoniidae) on the European pond turtle (Emys orbicularis) in northeast Algeria: Herpetology Notes, v. 10, p. 3-8.

Fielden, L.J., and Rechav, Y., 1994, Attachment sites of the tick Ambylomma marmoreum on its tortoise host, Geochelone pardalis: Experimental and Applied Acarology, v. 18, p. 339-349.

Fiorillo, A.R., 1987, Trample marks: caution from the Cretaceous: Current Research in the Pleistocene, v. 4, p. 73-75.

Fiorillo, A.R., 1991, Prey bone utilization by predatory dinosaurs: Palaeogeography, Palaeoclimatology, Palaeoecology, v. 88, p. 157-166.

Fourtau, R., 1920, Contribution a l'etude des vértebrès miocenes de l'Egypte: Cairo, Government Printing Office, $122 \mathrm{p}$.

Fritz, U., and Bininda-Emonds, O.R.P., 2007, When genes meet nomenclature: tortoise phylogeny and the shifting generic concepts of Testudo and Geochelone: Zoology, v. 110, p. 298-307.

Frye, F.L., 1991, Reptile Care, an Atlas of Diseases and Treatments: Neptune City, New Jersey, T.F.H. Publications, 637 p.

Gaffney, E.S., Meylan, P.A., Wood, R.C., Simons, E., and De Almeida Campos, D., 2011, Evolution of the side-necked turtles: the family Podocnemididae: American Museum Novitates, v. 350, 237 p.

Garner, M.M., Herrington, R., Howerth, E.W., Homer, B.L., Nettles, V.F., Izara, R., Shotts, E.B., Jr., and Jacobsen, E.R., 1997, Shell disease in river cooters (Pseudemys concinna) and yellow-bellied turtles (Trachemys scripta) in a Georgia (USA) lake: Journal of Wildlife Diseases, v. 33, p. 78-86.

Georgalis, G.L., Abdel Gawad, M.K., Hassan, S.M., El-Barkooky, A.N., and Hamdan, M.A., 2020, Oldest co-occurrence of Varanus and Python from Africa-first record of squamates from the early Miocene of Moghra Formation, Western Desert, Egypt: PeerJ, v. 8, e9092 http://doi.org/10.7717/peerj. 9092

Georgalis, G.L., Macaluso, L., and Delfino, M., 2021, A review of the fossil record of Afro-Arabian turtles of the clade Testudinoidea: Bulletin of the Peabody Museum of Natural History, v. 62, p. 43-78.

Ghirotti, M., and Mwanaumo, B., 1989, Amblyomma marmoreum on tortoises of the Southern Province, Zambia: Journal of Wildlife Diseases, v. 25 p. 634-635.

Graham, T.E., Saumure, R.A., and Ericson, B., 1997, Map turtle leech loads: The Journal of Parasitology, v. 83, p. 1185-1186.

Greene, G.E., 1983, Ectoparasites of the desert tortoise Gopherus agassizii, with emphasis on the soft ticks of the genus Ornithodoros (Acari: Argasidae), in Hashagen, K.A., and Trotter, M., eds., Proceedings of the 1983 Symposium of the Desert Tortoise Council; 1983, March 26-28, Lake Havasu City, Arizona: Long Beach, California, Desert Tortoise Council, p. $117-125$.

Grover, M.C., and DeFalco, L.A., 1995, Desert Tortoise (Gopherus agassizii): Status-of-Knowledge Outline with References: United States Department of Agriculture, Forest Service, Intermountain Research Station, General Technical Report INT-GTR-316, 134 p. 
Harbinson, C.F., 1937, The adobe tick on Gopherus agassizii: Herpetologica, v. 1, p. 80.

Harris, P.D., Shinn, A.P., Cable, J., and Bakke, T.A., 2004, Nominal species of the genus Gyrodactylus von Nordmann 1832 (Monogenea: Gyrodactylidae), with a list of principal host species: Systematic Parasitology, v. 59, p. 1-27.

Hasiotis, S.T., 2004, Reconnaissance of Upper Jurassic Morrison Formation ichnofossils, Rocky Mountain Region, USA: paleoenvironmental, stratigraphic, and paleoclimatic significance of terrestrial and freshwater ichnocoenoses: Sedimentary Geology, v. 167, p. 177-268.

Hassan, S.M., 2013, Sequence stratigraphy of the lower Miocene Moghra Formation in the Qattara Depression, north Western Desert, Egypt. Springer Briefs in Earth Sciences: New York, Springer, 160 p.

Hassan, S.M., Steel, R.J., El Barkooky, A., Hamdan, M., Olariu, C., and Helper, M.A., 2012, Stacked, lower Miocene tide-dominated estuary deposits in a transgressive succession, Western Desert, Egypt: Sedimentary Geology, v. 282 , p. $241-255$.

Hirayama, R., 1992, Fossil turtles from the Neogene strata in the Sinda Basin, Eastern Zaire: African Study Monographs, v. 17, p. 49-65.

Hofmeyr, M.D., Vamberger, M., Branch, W., Schleicher, A., and Daniels, S.R., 2017, Tortoise (Reptilia, Testudinidae) radiations in Southern Africa from the Eocene to the present: Zoologica Scripta, v. 46, p. 389-400.

Holroyd, P.A., and Parham, J.F., 2003, The antiquity of African tortoises: Journal of Vertebrate Paleontology, v. 23, p. 688-690.

Höpner, S., and Bertling, M., 2017, Holes in bones: ichnotaxonomy of bone borings: Ichnos, v. 24, p. 259-282.

Horak, I.G., McKay, I.J., Henen, B.T., Heyne, H., Hofmeyr, M.D., and De Villiers, A.L., 2006a, Parasites in domestic and wild animals in South Africa. XLVII Ticks of tortoises and other reptiles: Onderstepoort Journal of Veterinary Research, v. 73, p. 215-227.

Horak, I.G., Heyne, H., and Spickett, A.M., 2006b, Hosts, seasonality and geographic distribution of the South African tortoise tick, Amblyomma marmoreum: Onderstepoort Journal of Veterinary Research, v. 74, p. 13-25.

Hulse, A.C., 1976, Carapacial and plastral flora and fauna of the Sonora mud turtle Kinosternon sonoriense Le Conte (Reptilia, Testudines, Kinosternidae): Journal of Herpetology, v. 10, p. 45-48.

Hutchison, J.H., and Frye, F.L., 2001, Evidence of pathology in Cenozoic turtles: Paleobios, v. 21, p. 12-19.

Jackson, G.G., Jr., Jackson, M.M., and Davis, J.D., 1969, Cutaneous myiasis in the three-toed box turtle, Terrapene Carolina triunguis: Bulletin of the Wildlife Disease Association, v. 5, art. 114.

Jacobson, E.R., 1994, Causes of mortality and diseases in tortoises: Journal of Zoo and Wildlife Medicine, v. 25, p. 2-17.

Jacobson, E.R., 2007, Infectious Diseases and Pathology of Reptiles: London, CRC Press, Taylor and Francis, $716 \mathrm{p}$.

Johnson, C.A., Griffith, J.W., Tenorio, P., Hytrek, S., and Lang, C.M., 1998, Fatal trematodiasis in research turtles: Laboratory Animal Science, v. 48, p. $340-343$.

Kaiser, T.M., 2000, Proposed modification to fossil mammalian bone from PlioPleistocene hominid-bearing deposits of Laetoli (northern Tanzania): Annals of the Entomological Society of America, v. 93, p. 693-700.

Kaplan, H.M., 1957, Septicemic cutaneous ulcerative disease of turtles: Proceedings of the Animal Care Panel, v. 7, p. 273-277.

Karl, H-V., Gröning, E., and Brauckmann, C., 2012, Revision of Tropidemys seebachi Portis, 1878 (Testudines: Eucryptodira) from the Kimmeridgian (Late Jurassic) of Hanover (northwestern Germany): Studia Palaeocheloniologica, v. 4, p. 11-24.

King, W., and Griffo, J.V., 1958, A box turtle fatality apparently caused by Sarcophaga cistudinis larvae: Florida Entomologist, v. 41, p. 44.

Knipling, E.F., 1937, The biology of Sarcophaga cistudinis Aldrich (Diptera), a species of Sarchophagidae parasitic on turtles and tortoises: Proceedings of the Entomological Society, v. 39, p. 91-101.

Kuchling, G., 1988, Population structure, reproductive potential and increasing exploitation of the freshwater Erymnochelys madagascariensis: Biological Conservation, v. 43, p. 107-113.

Lafortune, M., Wellehan, J.F.X., Terrell, S.P., Jacobson, E.R., Heard, D., and Kimbrough, J.W., 2005, Shell and systemic hyalohyphomycosis in Fly River turtles, Carettochelys insculpta, caused by Paecilomyces lilacinus: Journal of Herpetological Medicine and Surgery, v. 15, p. 15-19.

Leidy, J., 1856, Notice of remains of extinct turtles of New Jersey, collected by Prof. Cook, of the State Geological Survey, under the direction of Dr. W. Kitchell: Proceedings of the Academy of Natural Sciences of Philadelphia, v. 8, p. 301-327.

Lindeman, P.V., 1996, Distribution, relative abundance, and basking ecology of the razorback musk turtle, Kinosternon carinatum, in the Pearl and Pascagoula river drainages: Herpetological Natural History, v. 4, p. 23-34.

Lindeman, P.V., 1999, Aggressive interactions during basking among four species of Emydid turtles: Journal of Herpetology, v. 33, p. 214-219.

Lovich, J.E., Gotte, S.W., Ernst, C.H., Harshbarger, J.C., Laemmerzahl, A.F., and Gibbons, J.W., 1996, Prevalence and histopathology of shell disease in turtles from Lake Blackshear, Georgia: Journal of Wildlife Diseases, v. 32 , p. $259-265$

MacCulloch, R.D., 1981, Leech parasitism on the western painted turtle Chrysemys picta belli, in Saskatchewan: The Journal of Parasitology, v. 67, p. $128-129$.

McCoy, J.C., Failey, E.L., Price, S.J., and Dorcas, M.E., 2007, An assessment of leech parasitism on semi-aquatic turtles in the western piedmont of North Carolina: Southeastern Naturalist, v. 6, p. 191-202.

Meylan, P., and Auffenberg, W., 1986, New land tortoises (Testudines: Testudinidae) from the Miocene of Africa: Zoological Journal of the Linnean Society, v. 86, p. 279-307.

Meylan, P., and Auffenberg, W., 1987, The chelonians of the Laetoli beds, in Harris, J.W., and Leakey, M.D., eds., Laetoli: A Pliocene Site in Tanzania: London, Oxford University Press, p. 62-78.

Mikulás, R., Kadlecová, E., Fejfar, O., and Dvorák, Z., 2006, Three new ichnogenera of biting and gnawing traces on reptilian and mammalian bones: a case study from the Miocene of the Czech Republic: Ichnos, v. 13, p. $113-127$.

Miller, E.R., 1996, Mammalian paleontology of an Old World monkey locality, Wadi Moghara, early Miocene, Egypt [Ph.D. dissertation]: St. Louis, Missouri, Washington University, $372 \mathrm{p}$.

Miller, E.R., 1999, Faunal correlation of Wadi Moghara, Egypt: implications for the age of Prohylobates tandyi: Journal of Human Evolution, v. 36, p. 519533.

Mitchell, M.A., 2007, Parasites of reptiles, in Baker, D.G., ed., Flynn's Parasites of Laboratory Animals (second edition): Ames, Iowa, Blackwell, p. 177216.

Mittermeier, R.A., 1971, Notes on the behaviour and ecology of Rhinoclemys annulata Gray: Herpetologica, v. 27, p. 485-488.

Moll, E.O., and Legler, J.M., 1971, The life history of a neotropical slider turtle, Pseudemys scripta (Schorpff) in Panama: Bulletin of the Los Angeles County Museum, Natural History, v. 11, p. 1-102.

Morlo, M., Miller, E.R., El-Barkooky, A.N., 2007, Creodonta and Carnivora from Wadi Moghra: Journal of Vertebrate Paleontology, v. 27, p. 145-159.

Morlo, M., Miller, E.R., Bastl, K., El-Barkooky, A.H., Hamdan, M., Abdel Gawad M., and Nagel, D., 2019, New Amphicyonids (Mammalia, Carnivora) from Moghra, early Miocene, Egypt, in Bonis L. de, and Werdelin, L., eds., Memorial to Stéphane Peigné; Carnivores (Hyaenodonta and Carnivora) of the Cenozoic: Geodiversitas, v. 41, p. 731-745.

Mueller, J.F., 1935, A Diphyllobothrium from cats and dogs in the Syracuse region: Journal of Parasitology, v. 21, p. 114-121.

Müller, F., 1846, Clepsine costata, neue Art.: Archiv für Naturgeschichte, v. 1, p. $82-85$.

Nielsen, K.S.S., and Nielsen, J.K., 2001, Bioerosion in Pliocene to late Holocene tests of benthic and planktonic foraminiferans, with a revision of the ichnogenera Oichnus and Tremichnus: Ichnos, v. 8, p. 99-116.

Noonan, B.P., 2000, Does the phylogeny of pelomedusid turtles reflect vicariance due to continental drift?: Journal of Biogeography, v. 27, p. 12451249.

Paik, I.S., 2000, Bone chip-filled burrows associated with bored dinosaur bone in floodplain paleosols of the Cretaceous Hasandong Formation, Korea: Palaeogeography, Palaeoclimatology, Palaeoecology, v. 157, p. 213-225.

Parren, S.G., 2013, A twenty-five year study of the wood turtle (Gylptemys insculpta) in Vermont: movements, behaviors, injuries and death: Herpetological Conservation and Biology, v. 8, p. 176-190.

Pérez-Garcia, A., de Lapparent de Broin, F., and Murelanga, X., 2016, The Erymnochelys group of turtles (Pleurodira, Podocnemididae) in the Eocene of Europe: new taxa and paleobiogeographical implications: Palaeontologia Electronica, v. 20.1.14A, 28 p., https://doi.org/10.26879/687

Peters, J.A., 1948, The box turtle as a host for dipterous parasites: American Midland Naturalist, v. 40, p. 472-474.

Radtke, G., and Golubic, S., 2005, Microborings in mollusk shells, Bay of Safaga, Egypt: morphometry and ichnology: Facies, v. 51, p. 118-134.

Ramaglia, V., Harapa, G.M., White, N., and Buck, L.T., 2004, Bacterial infection and tissue-specific HSP-72, -73 and -90 expression in western painted turtles: Comparative Biochemistry and Physiology, Part C, v. 138, p. 139148 .

Readal, A.M., Phillips, C.A., and Wetzel, M.J., 2008, Leech parasitism in a turtle assemblage: effects of host and environmental characteristics: Copeia, v. 2008 , p. $227-233$.

Reshke, N., 2009, Factors affecting leech parasitism on four turtle species in St. Lawrence Islands National Park [M.Sc. thesis]: Ottawa, University of Ottawa, $31 \mathrm{p}$.

Rinehart, L.F., Lucas, S.G., and Spielmann, J.A., 2006, Bite marks on tetrapod bones from the Upper Triassic Chinle Group representing a new ichnogenus: New Mexico Museum of Natural History Bulletin, v. 37, p. 160-163.

Roberts, E.M., Rogers, R.R., and Foreman, B.Z., 2007, Continental insect borings in dinosaur bone: examples from the Late Cretaceous of Madagascar and Utah: Journal of Paleontology, v. 81, p. 201-208. 
Rogers, R.R., 1992, Non-marine borings in dinosaur bones from the Upper Cretaceous Two Medicine Formation, northwestern Montana: Journal of Vertebrate Paleontology, v. 12, p. 528-531.

Rose, F.L. Koke, J., Koehn, R., and Smith, D., 2001, Identification of the etiological agent for necrotizing scute disease in the Texas tortoise: Journal of Wildlife Diseases, v. 37, p. 223-228.

Rothschild, B.M., 2009, Scientifically rigorous reptile and amphibian osseous pathology: lessons for forensic herpetology from comparative and paleopathology: Applied Herpetology, v. 6, p. 47-79.

Rothschild, B.M., Schultze, H.P., and Pellegrini, R., 2012, Herpetological Osteopathology: Annotated Bibliography of Amphibians and Reptiles: New York, Springer, $450 \mathrm{p}$.

Rothschild, B.M., Schultze, H-P., and Pellegrini, R., 2013, Osseous and other tissue pathologies in turtles and abnormalities in mineral deposition, in Brinkman, D.B., Holroyd, P.A., and Gardner, J.D., eds., Morphology and Evolution of Turtles: Dordrecht, Springer, p. 501-534.

Rudolphi, K.A., 1819, Entozoorum synopsis cui accedunt Mantissa duplex et indices locupletissimi: Berolini, Sumtibus Augusti Rücker, 824 p.

Ryan, T.J., and Lambert, A., 2005, Prevalence and colonization of Placobdella on two species of freshwater turtles (Graptemys geographica and Sternotherus odoratus): Journal of Herpetology, v. 39, p. 284-287.

Ryckman, R.E., and Kohls, G.M., 1962, The desert tortoise, Gopherus agasizii, a host for the tick Ornithodoros turicata in California: Journal of Parasitology, v. 48, p. 502-503.

Said, R., 1962, The Geology of Egypt: Amsterdam, Elsevier, 377 p.

Sanders, W.J., and Miller, E.R., 2002, New proboscideans from the early Miocene of Wadi Moghara, Egypt: Journal of Vertebrate Paleontology, v. 22, p. 388-404.

Scheyer, T.M., and Sánchez-Villagra, M.R., 2007, Carapace bone histology in the giant pleurodiran turtle Stupendemys geographicus: phylogeny and function: Acta Palaeontologica Polonica, v. 52, p. 137-154.

Schneider, J.G.T., 1783, Allgemeine Naturgeschichte der Schildkröten: nebst einem systemischen Verzeichnisse der einzelnen Arten und zwey Kupfern: Leipzig, Johan Gotfried Müllerschen Buchhandlung, 32 p.

Siddall, M.E., and Gaffney, E.S., 2004, Observations on the leech Placobdella ornata feeding from bony tissues of turtles: Journal of Parasitology, v. 90, p. $1186-1188$.

Simons, E.L., 1969, Miocene monkey Prohylobates from northern Egypt: Nature, v. 223, p. 687-689.

Simmons, L-A., and Burridge, M.J., 2000, Introduction of the exotic ticks Amblyomma humerale Koch and Amblyomma geoemydae (Cantor) (Acari: Ixodidae) into the United States on imported reptiles: International Journal of Acarology, v. 26, p. 239-242.

Sinn, A.D., 2004, Pathologie der Reptilien - eine retrospektive Studie [Ph.D. thesis]: München, Ludwig Maximilian Universität, 160 p.

Spix, J.B., 1824, Animalia nova sive species novae Testudinum et Ranarum, quas in itinere per Brasiliam annis MDCCCXVII - MDCCCXX Iussu et Auspiciis Maximiliani Josephi I. Bavariae Regis suscepto collegit et descripsit: Munich, Typis Franc. Seraph. Hübschmanni, 29 p.

Stromer, E.V., 1926, Rest land und Susswaser-Bewohnender Wirbluere aus den Diament-feldern Deutsch Sudwestafrikas, in Kaiser, E., ed., Die Diamentenwuste Sudwestafricas: Berlin, D. Reimer, p. 139-142.

Tapanila, L., Roberts, E.M., Bouaré, M.L., Sissoko, F., and O'Leary, M.A., 2004, Bivalve borings in phosphatic coprolites and bone: Palaios, v. 19, p. 565-573.

Tappan, M., 1994, Bone weathering in the tropical rain forest: Journal of Archaeological Science, v. 21, p. 667-673.
Tasnádi-Kubacska, A., 1962, Paläopathologie, Pathologie der vorzeitlichen Tiere: Jena, Fischer, 269 p

Tchernov, E., 1986, Evolution des crocodiles en Afrique du Nord et de l'Est (Cahiers de paléontologie): Paris, Editions du Centre National de la Recherche Scientifique, $65 \mathrm{p}$.

Thomas, H., et al., 1991, Essai de reconstitution des milieux de sédimentation de vie des primates anthropoïdes de l'Oligocène de Taqah, (Dhofar, Sultanat d'Oman): Bulletin de la Société Géologique de France, v. 262, p. 713-724.

Vallon, L.H., Rindsberg, A.K., and Martin, A.J., 2015, The use of the terms trace, mark and structure: Annales Societatis Geologorum Poloniae, v. 85 , p. $527-528$.

Verrill, A.E., 1872, Brief contributions to zoology from the Museum of Yale College; no. XVII. Descriptions of North American fresh-water leeches: American Journal of Science, v. 3, p. 126-139.

Vialov, O.S., and Nessov, L.A., 1974, Post-mortem injuries of the shells of some Early Cretaceous turtles by bone damaging organisms: Paleontologicheskiy Sbornik, v. 11, p. 99-103. [in Russian]

Vogt, R.C., 1979, Cleaning/feeding symbiosis between grackles (Quiscalus: Icteridae) and map turtles (Graptemys: Emydidae): The Auk, v. 96, p. 608-609.

Wallach, J.D., 1975, The pathogenesis and etiology of ulcerative shell disease in turtles: Journal of Zoo Animal Medicine, v. 6, p. 11-13.

Waller, T., Micucci, P.A., and Richard, E., 1989, Preliminary Results on the Research on the Biology, Ecology and Conservation of the Chelonoidis chilensis (sensu lato) (Gray, 1870) Tortoise in Argentina (Testudines: Testudinidae): Buenos Aires, K.Z.T., WWF - TRAFFIC Sudamérica and CITES Secretariat Publication, $43 \mathrm{p}$.

Wells, C., 1964, Bones, Bodies and Disease: Evidence of Disease and Abnormality in Early Man: London, Thames and Hudson, 288 p.

Williams, E.,1954, New or redescribed pelomedusid skulls from the Tertiary of Africa and Asia (Testudines, Pelomedusidae): Breviora, v. 35, p. 1-9.

Wisshak, M., Seuß, B., and Nützel, A., 2008, Evolutionary implications of an exceptionally preserved Carboniferous microboring assemblage in the Buckhorn Asphalt Lagerstätte (Oklahoma, USA), in Wisshak, M., and Tapanila, L., eds., Current Developments in Bioerosion: Berlin, Springer, p. 21-54.

Wisshak, M., Meyer, N., Radtke, G., and Golubic, S., 2018, Saccomorpha guttulata: a new marine fungal microbioerosion trace fossil from cool- to coldwater settings: Paläontologische Zeitschrift, v. 92, p. 525-533.

Wisshak, M., Knaust, D., and Bertling, M., 2019, Bioerosion ichnotaxa: review and annotated list: Facies, v. 65, art. 24.

Woodbury, A.M., 1952, Hybrids of Gopherus berlandieri and G. agassizii: Herpetologica, v. 8, p. 33-36.

Woodbury, A.M., and Hardy, R., 1948, Studies of the desert tortoise, Gopherus agassizii: Ecological Monographs, v. 18, p. 145-200.

Zonneveld, J-P., and Bartels, W.S., 2019, Ichnologic note: in defence of Thatchtelithichnus Zonneveld, Bartels, Gunnell and McHugh, 2015: Ichnos, v. 27, p. 152-255.

Zonneveld, J-P., Bartels, W.S., Gunnell, G.F., and McHugh, L.P., 2016, Borings in early Eocene turtle shell from the Wasatch Formation, South Pass, Wyoming: Journal of Paleontology, v. 89, p. 802-820.

Accepted: 6 September 2021 